U. S. DEPARTMENT OF COMMERCE NATIONAL BUREAU OF STANDARDS

\title{
STANDARDIZATION OF PACKAGES
}




\section{U. S. DEPARTMENT OF COMMERCE \\ HARRY L. HOPKINS, Secretary \\ NATIONAL BUREAU OF STANDARDS \\ LYMAN J. BRIGGS, Director}

NATIONAL BUREAU OF STANDARDS MISCELLANEOUS PUBLICATION M165

\section{STANDARDIZATION OF PACKAGES}

[Reprinted from Miscellaneous Publication M164]

Issued April 2, 1940

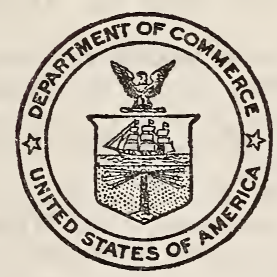

UNITED STATES

GOVERNMENT PRINTING OFFICE

WASHINGTON : 1940 


\section{PREFACE}

The material comprising this publication is a direct reprint from National Bureau of Standards Miscellaneous Publication M164, Report of the Twenty-Ninth National Conference on Weights and Measures, and presents the full text of the report for the fifth and sixth sessions of the Conference, which were devoted entirely to the subject of standardization of packages. This publication is being issued to meet a demand from individuals and groups particularly interested in questions relating to package standardization.

LYMaN J. Briggs, Director.

\section{CONTENTS}

Report of Committee on Standardization of Packaged Goods of the National Conference on Weights and Measures, presented by Alex Pisciotta, chairman

Paper presented by Hazel Kyrk, Home Economics Department, University of Chicago, representing the American Home Economics Association

Paper presented by Hector Lazo, executive vice president, Cooperative Food Distributors of America

Discussion of above paper Paper presented by Carlos Campbell, director of the Division of Statistics,
National Canners Association Discussion of above paper Paper of Arthur P. Williams, president,
ing the National Wholesale Grocers' Associatioms and Co., representDiscussion of above paper

Paper presented by F. F. Fitzgerald, director of research, American Can Co., representing the Can Manufacturers Institute, Inc American Can Discussion of above paper.......

Paper presented by J. S. Algeo, Hazel-Atlas Co, representing the Glass Container Association of America

Paper presented by Charles $R$. Cosby, executive secretary, Label Manufacturers National Association

General discussion of report of conference committee 


\section{FIFTH SESSION-MORNING OF THURSDAY, JUNE 8, 1939}

(The Conference reassembled at 9:50 a. m., at the Washington Hotel; W. S. Bussey, Vice President of the Conference, in the chair.)

\section{STANDARDIZATION OF PACKAGES}

The Acting Chamran. During the past year there was appointed by the president of the Conference a special committee to study the question of standardization of packages. Mr. Pisciotta will now present tbe report of his Committee.

\section{REPORT OF CONFERENCE COMMITTEE, PRESENTED BY ALEX FISCIOTTA, CHAIRMAN}

At the Twenty-eighth National Conference on Weights and Measures last year following the delivery and discussion of a paper by Director Alex Pisciotta, of the Bureau of Weights and Measures, New York City, a motion was adopted that a committee be appointed to look into the matter of remedying the situation as to the standardization of packages and to determine which way may be best adopted to accomplish that purpose. Subsequent to this the Committee on Resolutions introduced a resolution which was adopted endorsing the principle of general standardization of packaged goods as follows:

Whereas we have knowledge of the benefit which would accrue from a standardization of all packaged goods; Therefore be it

Resolved, That this, the Twenty-eighth National Conference on Weights and Measures, does hereby record its sincere belief that a general standardization of packaged goods is greatly to be desired, and does direct its Executive Committee to consider ways and means of accomplishing this.

An almost identical resolution was also adopted at the Twentyseventh Conference in 1937.

Dr. Briggs, president of the National Conference, appointed seven members of the Conference to serve as the National Conference Committee on Standardization of Packaged Goods.

The need for prompt, effective action is imperative and is increasing rapidly. George Warner's paper on the standardization of packages of canned goods delivered at the Twenty-seventh Conference in 1937 and Mr. Pisciotta's paper on the standardization of packages in general at the Twenty-eighth Conference in 1938, and the general discussion which followed these papers brought out the facts regarding this fast-growing new method of cheating the consumer-because that's what it really is.

For generations commodities have been dealt in by standard units of weight and measure, particularly the pound, quart, gallon, etc. Business methods have changed and with the growth of chain stores, self-service stores, and the packaging of commodities in general, the sale of commodities which are weighed by the retailer is fast disappearing. Sale by package is now the usual thing. Competition is very keen in this class of business and has resulted in unfair practices and in all sorts of odd-sized, misleading, and deceptive packages. The consumer is being misled and deceived and of ten cheated outright. 
Honest, ethical dealers, packers, and distributors are forced, in orde to meet competition, to follow the lead of their competitors ani adopt practices which they know to be irregular and which, in man! cases, lead to conditions which are not to the best interests of th. majority of the producers themselves.

For example, coffee. This has always been bought by the pound everybody asks for a pound of coffee, or perhaps a half pound Through competition, in trying to meet or to beat the price of thi other fellow, we find 7-ounce packages, 8-, 13-, 14-, and 15-ounce cans, and the standard 16-ounce, or 1-pound, cans. There is nc justification for the packing of coffee in these odd sizes, nor is there any justification in the packing of tea in $3-, 3 \frac{1}{2-}$, or 7 -ounce packages, which is also being done.

Large distributors and chain stores have identical-sized packages for all staple commodities put out by them, such as rice, barley, dried beans of all kinds, peas, etc. In a list of 10 such distributors we find that for 8 such commodities, 6 of the 10 distributors put up these commodities in full-pound weights. One distributor put up only one commodity in a full pound, and put up five in the odd weight of $14 \frac{1}{2}$ ounces. Some distributors have identical packages containing two different weights of the same commodity, for instance, pea beans in 14- and 16-ounce packages and barley in 13- and 16-ounce packages. There is no excuse or justified explanation for this. These distributors argue that they purchase millions of containers of a standard size and use the same package for different commodities. They claim that their standard box, for example, will hold only 15 ounces of green split peas, $14 \frac{1}{2}$ ounces of pea beans, a full pound of lentils, and so on. They argue that by using only the standard-sized box and purchasing them in very large quantities, there is a great saving which is passed on to the consumer.

This argument is absolutely false, as is proved by the fact that other distributors can and do pack all their commodities in full-pound boxes of identical size. Furthermore, some of them do pack 14 and 16 ounces of the same commodity in the same standard-sized boxes.

L. J. Salter, of the Salter Canning Co., in a communication to the Committee on Coinage, Weights, and Measures of the House of Representatives in support of bill H. R. 6964, the Sauthoff bill, lists 15 different cans of tomato juice between 7 ounces and 1 pound 15 ounces and 14 different cans for tomato soup between $73 / 4$ ounces and 2 pounds 2 ounces. Taking them both together, there are 29 different quantities listed in a range of 27 ounces. In this same range there are only 15 cans listed. Some of them contain two different quantities, probably because tomato soup is heavier. It is interesting to note that in the entire list of 29 different quantities there are only two cans which contain an even pound and only one which contains threequarters of a pound. These are all that might be termed standard.

Beer is being sold in New York City, and probably elsewhere, in containers of the following sizes: $61_{2}-, 7-, 10-, 11 \frac{1}{2_{2}^{-}}, 12-, 26-, 29-, 30-$, and 32-ounce, or 1 quart. Through pressure on the part of the New York City Bureau of Weights and Measures, the 29-ounce bottle has been voluntarily discontinued by the brewer, who is now using the full-quart size. The brewery now putting up beer in the 10- and 30 -ounce bottles formerly used the usual 12-ounce and 1-quart sizes but changed to the smaller quantities to meet competition. 
In Wisconsin they have a law which requires that the actual weight or volume of the contents of food in package form be conspicuously set forth in not less than 10-point type in any advertisement when the retail price is mentioned.

Lately the matter of fiber or paper milk bottles has become prominent. In New York and several other States the weights and measures authorities have classed these as milk bottles and limited them therefore to the standard sizes allowed for milk bottles. Other States handle this in other ways, but all seem to be agreed that odd-sized fresh milk containers be not allowed to come into use. A representative of the largest manufacturer of these paper containers informed a New York weights and measures official that his firm had already been approached to manufacture a 6-ounce size of these containers, but had refused. Evidently, therefore, unless definitely checked, this evil of odd-sized packages will spread into the fresh milk industry.

Many retailers do not know the quantity in many of the packages which they sell every day. In the city of New York within 1 week during the Jewish Passover, inspectors of the Bureau of Weights and Measures obtained 1,100 violations against storekeepers, by asking for a 5-pound package of matzohs and being handed a package which was marked 4 pound, 9 ounces. In almost every case the storekeeper was asked if it was a 5-pound package, then the price per pound; the price quoted was made on the basis of 5 pounds at so much per pound. The matzohs were called "Fives" and were so billed to the retailer. A reporter on a newspaper with one of the largest sales in New York and throughout the East was preparing an illustrated article on the different sizes of beer bottles sold in New York. The weights and measures authorities asked him to go to the first store he met with on his way downtown and ask for a quart bottle of a certain kind of beer and to make it clear to the storekeeper that he wanted a quart bottle. He did so and was handed a 29-ounce bottle which the storekeeper insisted was a quart. To make it more complicated, it was labeled 1 pint 13 ounces.

One of the members of the Committee on Coinage, Weights, and Measures during the discussion of the Sauthoff bill stated, "Then there is no deception so far as the label is concerned?" Later in the hearing he admitted that he never reads the contents on the label. To suggest that the millions of consumers should memorize the weights of different-sized packages to escape being fooled, places the burden of proof on the consumer and is thereby an imposition.

It is apparent that canners, packers, distributors, and others rely on the old policy of "caveat emptor," or "Let the buyer beware." In other words, the consumer purchases at his own risk and is bound to protect himself as best he can against fraud and deception. That this is no longer the case-if it ever were true-is shown by the following extract from an opinion of the Supreme Court of the United States in a decision on November 8, 1937:

The fact that a false statement may be obviously false to those who are trained and experienced does not change its character nor take away the power to deceive others less experienced. There is no duty resting upon a citizen to suspect the honesty of those with whom he transacts business. Laws are made to protect the trusting as well as the suspicious. The best element of business has long since decided that honesty should govern competitive enterprises and that the rules of "caveat emptor" should not be relied upon to reward fraud and deception. 
Along these lines, and in conformity with this changing policy, the Supreme Court in a decision stated that few purchasers read long labels; many cannot read them at all. A Federal judge recentiy charged a jury as follows:

The law requires a manufacturer to be honest in his statement of the contents of a package containing a food product and it requires him to be honest in stating the truth of the labels put on it. It is the purchasing public, the ultimate consumer, whom the provisions of the law are primarily intended to protect. The law is not made for the protection of experts, but for the people, that vast multitude which includes the ignorant, the unthinking, and the credulous who, in making purchases, do not stop to analyze but are governed by appearances and general impression. It makes no difference that dealers in the article are not deceived. It is the probable inexperience of the customer that you should consider.

It can be seen from the above rulings that there is an obligation resting upon the merchant to so represent the commodities he sells that the average person can safely rely on the representation as it is understood by the customer.

The complaint is frequently heard that there is too much Government control in business. Whether this is true or not in general, the fact remains that it is frequently, perhaps too often, necessary for some governmental agency to step in and remedy conditions when business has failed to do this for themselves. A means of correcting conditions for themselves is provided through the agency of the Division of Simplified Practice of the National Bureau of Standards. However, this is based entirely on voluntary cooperation and the United States Department of Commerce has no regulatory powers with respect to simplified practice. As a matter of fact, the failure of voluntary agreements was pointed out at the hearing on the Sauthoff bill. The can makers could settle the problem by coming to an agreement, but they will not and they comprise only five or six corporations. It is too much to expect that 3,000 canners will agree. A number of the very largest canners did not sign the voluntary agreement and were therefore not bound by it.

This Conference for the past 2 years endorsed for passage the Sauthoff bill in Congress, which was aimed at the standardization of canned fruits, vegetables, and milk. This bill provided for the standardization on the basis of the standard liquid measures, that is, gill, pint, quart, and gallon. However, the Somers bill, although it reduces the large number of different sizes and shapes of cans, gets away from the standardization on the basis of standard weight or measure.

In the Somers bill there are nine cylindrical cans included for fruits and vegetables and three for evaporated milk. There are two rectilinear containers included for fruits and vegetables. This Committee is not aware of the reason dictating the inclusion of the particular sizes. There must be good reason for this selection. However, a computation of the capacity in cubic inches indicates that none of them has an exact capacity in terms of liquid measure, the nearest being the largest-sized container specified for evaporated milk, which will contain 231.16 cubic inches, or a trifle more than a gallon. That the capacity by avoirdupois weight will vary with the commodity is obvious. The capacity by avoirdupois weight of distilled water at $68^{\circ}$ Fahrenheit is given in the law to two decimal places.

The Committee, after a careful study, is definitely opposed to the standardization of containers except in terms of standard contents. 
[his is true of everything standardized or proposed to be standardized. jy Federal law so far-till baskets or boxes, climax baskets, hampers, ound-stave baskets, market baskets, standard barrels, etc. Any size or shape container is permitted for dry fruits and vegetables provided the net weight or numerical count is marked thereon. Weights and measures officials should not be interested in the standardization or simplification of container sizes when it conflicts with their duty. There is much room for standardization and simplification in containers which can be done without creating the multiplicity of varied contents. For example, everything that is sold by liquid measure can be easily and readily standordized both by size and by shape. If there is any sincerity in this standardization and simplification, let them adopt the standard units and submultiples of the gallon as we recommend in this report.

It is obvious that standardization of the size of containers of commodities sold by net weight can only be had by sacrificing the standardization of the net weight. If they desire to standardize, let them agree to pack in standard quantities and then all agree to pack the same commodity in standard-sized containers. Then all catsup would be standard and all the bottles would be identical-all tomato juice, which should be sold by liquid measure, would be in standard cans or bottles all identical in shape or size. Why should the consumer have to worry about a "No. 2" can, or a "No. 3," or any other stock designation. All she knows or should know is what she was taught in school as standards of weight or measure. If this is true of fresh inilk, packaged butter, paint, and a number of other commodities, why shouldn't it be true of all?

It may be true that standardization and simplification of metal containers might result in reduced costs which would be passed along to the consumer. In the hearings on the Sauthoff bill the canners argued otherwise. We have been informed by a representative of the canning industry that there are now 27 different-sized containers for tomato juice and soup. If they are now using 27 different sizes for these commodities in a range of 27 ounces, think of the saving if only a few sizes were allowed.

It seems certain that the passage of the Somers bill in its present form will operate to the disadvantage of standardization of packages by contents for other commodities than those included in the bill (fruit and vegetables and evaporated milk). How can you expect to legislate the standardization of vegetable soup or canned spaghetti by standard weight or measure if tomato juice or canned peas can be legally put up in odd measure or weight, as would be permitted by the present Somers bill?

On pages 125,126 , and 127 of the report of the hearing on the Sauthoff bill, the evaporated milk industry states the reasons for the change from a 16-ounce can to a tall can of 14.5 ounces. Among numerous reasons, most of which do not sound conclusive, you will find the desire to make it a 5- and 10-cent seller. Once having decided on that, the industry "developed" other factors. It is necessary in order to compare values to determine the weight or measure contained in the can. For example, a customer found she could get two No. 5 cans of corm for 23 cents or two No. 6 cans for 25 cents. It would take a long time for the average consumer to figure that 
out, and she wouldn't know any more about it if she saw the can; they would look much alike although containing different quantities.

The Committee held an all-night session last Monday, June 5, and had the pleasure of the presence of Carlos Campbell, Director, Division of Statistics of the National Canners Association. The subject was fully discussed and we received some very helpful suggestions from Mr. Campbell.

From all the data that the Committee has been able to investigate it is obvious

(1) That containers can be made of practically any sizes and shapes.

(2) That the size of the container is not regulated by canning problems or simplified practice, but by competition and the "whims" of the packer.

(3) Container sizes are frequently made to sell at an arbitrary price, such as a nickel or a dime; however, a standard price has been hard to fix. Every store will sell at its own price depending on location, type of customers, and other factors.

(4) Too frequently it is considered more advisable to decrease the size of the package in order to maintain the old price as the cost of the commodity fluctuates.

\section{CONCLUSIONS}

(1) There is absolute necessity for the standardization of the quantities of all commodities now sold in packages or containers, whether of food or otherwise.

(2) Present practice leads to fraud, deception, and unfair competition.

(3) Due to the interstate nature of this problem it must be remedied by Federal law.

(4) Simplified practice is a voluntary activity; there is no means of enforcing it and it is only effective to the extent that it is accepted voluntarily by a sufficiently large number of those affected.

(5) The Somers bill should be amended to provide for standardization by liquid measure for commodities sold by liquid measure, all containers of the same quantity to be of identical dimensions.

(6) For commodities in metal containers included in the Somers bill which are sold in terms of weight, the base dimensions of the container should be standardized leaving the height to be regulated for each commodity, these commodities to be put up in standardized quantities of avoirdupois weight.

\section{RECOMMENDATIONS}

The Committee recommends that Federal legislation be initiated standardizing the quantities of all commodities sold in packages or containers of any kind and that the Somers bill be amended so as not to conflict with such recommended legislation; that the standard be restricted to avoirdupois weight in the following capacities:

(1) $1,2,3$, and 4 ounces; both fluid and avoirdupois weight.

(2) 6 fluid ounces for fruit juices only, where contents of container is sold to be consumed on the premises. (The reason for this is the requirement of the industry for hotel and restaurant use; a 6-ounce glass of fruit juice is usually served.) 
(3) $8,12,16,24$, and 32 ounces avoirdupois weight, and multiples of the pound thereafter.

(4) $8,12,16,24$, and 32 fluid ounces and multiples of the pint to the $1 / 2$ gallon; $1 / 2$ gallon and gallon; and multiples of 1 gallon thereafter.

(5) Containers of different standards to be so constructed that the different sizes are easily discernible, this to be accomplished by fixing the diameter or the base measurements of the container and letting the industry change the height of the respective containers to fit the particular commodity.

(6) The height of the container to be no more than is required for the particular commodity at the time of packing, bottling, or canning, so as to allow for cooling or natural shrinkage.

(7) The net weight or net measure to be in the above units not at the time of packing, bottling, or canning, but at the time of sale to the consumer.

Respectfully submitted,

(Signed) Alex Piscrotta, chairman,

JAMES O'KEEFE,

C. D. BAUCOM,

C. E. TUCKER,

C. L. KLOCKER,

R. L. FULLEN,

George Warner,

Committee on Standardization of Packaged Goods.

Mr. Pisciotra. May I suggest that we dispense with any discussion of this report until we hear what the members of the industry have to say about their side of the story? After we have had an opportunity to hear them, we will all have an opportunity to discuss this measure and take any position we desire to take on the report. Discussion now, without hearing any comments pro or con would be practically a waste of time.

(A motion was made and seconded that this suggestion be followed, the question was taken, and the motion was agreed to.)

PAPER PRESENTED BY DR. HAZEL KYRK, HOME ECONOMICS DEPARTMENT, UNIVERSITY OF CHICAGO, REPRESENTING THE AMERICAN HOME ECONOMICS ASSOCIATION

I do not need to give this group evidence of the great increase in the sale of packaged goods, and the increasing frequency of their sale in a multiplicity of odd-sized and odd-shaped packages. I do, however, want to assure you that the facts about this situation and the dangers inherent in it are increasingly being noted by consumers and being brought to their attention by an increasing number of agencies.

I would like to summarize briefly what, it seems to me, are the objections to this aspect of the market situation from the consumerbuyer's standpoint. In the first place, there is a very real danger of deception, or, if you prefer to call it so, of mistake as to quantity. This danger takes two or three different forms. There is in the first place the baldest kind of what most certainly should be called deception, equivalent to short-weighting, when the customer asks for a pound or half pound of a commodity and is handed a package containing less than this amount. But there is also the deception or mistake that occurs when the buyer assumes from shape and appearance that a package contains more than it does, or as much as another, when in fact it does not. Allied to this is the error that is occasionally 
made of assuming from the unchanged size and appearance of a packag that it contains as much as it formerly did.

I have in my possession a clipping from a trade paper in which \& firm selling vanilla announces, "The B- vanilla bottle is now aI honest bottle." Up to that time it presumably had been a dishonest bottle, with paneled sides and with length excessive for its widtha bottle intended to deceive. I hope this confession was good for their sales as well as for their souls. Now it is an honest bottle (I have seen it), and one that will stand without tipping.

But deception is not the only ground for objection to the present miscellany of containers in which goods are packed. Another is the obstruction it offers to the making of those price comparisons that are essential, not only for individual economy in the narrow sense, but for the proper functioning of our individualistic economy in the broader sense. If the buyer is to get the most for her money, she must make price comparisons and select the article of given quality at the lowest price at which it is offered. I will say nothing of her ability to determine quality; that is another problem. Quantity, however, she must know in order that she may make price comparisons in a standard unit of measurement, per ounce, pound, pint; whatever is appropriate. But to what extent will this happen, can this happen, in the case of those articles offered in a multiplicity of odd-sized containers? She would be obliged to come to the market with pencil and paper and spend some time in calculation after getting the price quotations. Mental arithmetic would not suffice. Note even the difficulty that often confronts her in comparing the actual price per standard unit of the "small," "medium" and "large" packages of one concern; the "small" may contain 31/2 ounces, the "medium" 8, the "large" 14. On what basis, one wonders, are these sizes arrived at. There are instances when they result in marked inconvenience and waste in use, as in the case of evaporated-milk cans. The small size does not hold quite a cup and the large not quite two cups, so that in any use as an ingredient with the measurement other than in cans, there is always not quite enough or too much.

Note also that no market is a truly competitive market where buyers cannot or do not make price comparisons-between dealers, between various brands, and between the branded and the unbranded, if such there be. Among the specifications for a "freeenterprise" society that really has the economic advantages it is supposed to have, is informed buyers, zealously seeking the lowest price for a given quality and best quality at a given price. The market that withholds information, gives misinformation, attempts to deceive, makes price comparisons difficult, is not a market according to the ideal plan.

It has therefore long been my opinion that one of the next steps in the regulation of weights and measures is legislation designed to eliminate the slack-filled and the deceptively shaped and constructed package, to reduce the present multiplicity of sizes to the minimum made necessary by the different uses and different users of the product and, finally, to substitute for the odd sizes, insofar as the nature of the product permits, those sizes that are easily calculable multiples or fractional parts of the unit of measurement appropriate for each commodity. 
There is one issue that it seems to me should be brought up in this zonnection and carefully thought through. That is, is plain and sonspicuous marking of the net weight or measure of the contents idequate remedy for the dangers and difficulties complained of? If the packages are so marked, has the buyer just cause for complaint? May the canner and packer properly say that the root of the evil is consumer ignorance and carelessness, that if she will not take heed, (that is, compute and compare) let her suffer the consequences?

Plain and conspicuous marking, although essential, would not of coirse reduce the effort or the time-cost of making price comparisons. In any discussion involving the buyer in the retail market, it is also well to be realistic. This buyer is far different from the buyer for resale or manufacture. Buying by the consumer is but one of many activities and responsibilities. The ccnsumer buys not one commodity or related group of commodities but a wide variety of diverse character, some only infrequently. The buying is in small quantities. The question is not only what could consumer-buyers do, but what are they likely to do, and what are the economic consequences of what they will do.

Moreover, if it is granted that the multiplicity of sizes and the odd sizes are an inconvenience, time consuming, mistake promoting, why may we not rid the market of them? We do not set traps for ourselves, or try to make life more difficult than it need be. One question that should be asked about every market practice is, does it make buying an easier process? Does it reduce or increase mistakes? What are we to say of a market situation in which the buyer must use time and energy in avoiding deception, in discovering the concealed price change? Rather, I would say, let us make the market as mistake-proof, deception-proof, even fool-proof, as possible. Some changes proposed to bring this about involve expense, expense that will and should be reflected in the price of the goods. But this proposed change presumably would not increase, and might even decrease, the money costs of putting the goods on the market.

We need the plain and conspicuous marking of the net weight, measure, or numerical count of the contents of all containers in the standard unit of measurement that is appropriate. In addition, we need standardized containers, the number, size or capacity, and character of which have been determined by three things:

1. The nature of the commodity and the process of packing, shipping, or storing it.

2. Market demand for packages of various sizes.

3. Ease in making price comparisons and the reduction of mistake or deception as to quantity.

The Acting Chairman. Thank you, Dr. Kyrk. The Conference is certainly obliged for your discussion.

Before we recess, I want to ask our Vice President from the Hoosier State to assume charge of the meeting this afternoon. Let us all make an effort to be back here in time to resume the sessions at 1:30.

(At this point, at 10:51 a. m., the Conference took a recess until 1:30 p. m.) 



\section{SIXTH SESSION-AFTERNOON OF THURSDAY, JUNE 8, 1939}

(The Conference reassembled at 1:50 p. m., at the Washington Hotel; Rollin E. Meek, vice president of the Conference, in the Chair.)

\section{STANDARDIZATION OF PACKAGES-Continued}

PAPER PRESENTED BY HECTOR LAZO, EXECUTIVE VICE PRESI. DENT, COOPERATIVE FOOD DISTRIBUTORS OF AMERICA

Mr. Chairman, ladies, and gentlemen: I approach this with some besitancy, because I have never found it worth while to pretend to be an expert in things I know very little about, and I know very little about the technicalities of this subject.

I have a very definite picture in mind of the type of distributor that we represent, the type of distributor that is concerned with this problem, and the type of distributor who welcomes the activities of the National Conference in recent years and recent months towards reducing the multiplicity of containers of all kinds, and making, shall we say, a common-sense approach towards a reduction of all these things that are quite as confusing to my dealers as they are to the consumers.

We are aware of the fact that, traditionally, distributors are supposed to be some sort of poorly disguised enemies of the consumer, and hence if the consumer sponsors a program of more informative labeling, of greater standardization of containers, a reduction in the multiplicity of can sizes in canned goods, we, as distributors, should be against it. Of course, that is all poppycock.

Actually, distributors are, or should be, very definitely for any program which (1) reduces the number of cans and other containers to a minimum consistent with good business and common sense, (2) establishes practical informative labeling with a common-sense approach to the very real problem of standards of both weight and quality, and (3) affords the consumer full and accurate information as to the quality and quantity of the contents.

And why shouldn't we be for such a program? Would not such a program mean greater sales and more repeat sales for us?

Frankly, there is quite a group-and I hope it is growing-among distributors who think that, selfishly if for no other reason, the distributor's interests must be tied up directly with the wishes of the consumer. And by that we do not mean inventing phantom consumer desires but actually trying to take the consumer point of view and, wherever possible, complying with such desires.

Now, obviously, consumers may be acting under either fair and full information, in which case intelligent consumers can be generally trusted to act pretty sanely, or else they may be acting under partial or even false information, in which case their actions might be open to question, perhaps even opposition on our part. But if the consumer is not fully informed, whose fault is it?

Is there anything now preventing us, as distributors, from telling the consumer in simple terms, what, let us say, and how much, this can 
of vegetables contains? A myriad of practical considerations immediately rise; to the extent that they are practical obstacles, and not merely selfish inventions of our own, the consumer ought to be willing to listen to reason. But we must be prepared to supply those reasons. The consumer may know definitely what he or she wants, and in the absence of better information to the contrary, may even believe that Government grade labeling for quality and a similar Government standard for quantity will supply the answer to her prayer. If, as most distributors believe, Government grade labeling is not the best solution, what is? And what are we doing to persuade Mrs. Consumer that it isn't?

Many good people shudder at the thought of Government grade labeling, and the trade as a whole is opposed to this. There are many and weighty arguments why the trade takes this point of view. Most of you gentlemen know these much better than I do. But what does Mrs. Consumer think about this? Does she understand our reasoning in the matter, as against the reasoning of those who advocate Government grade labeling and Government standardization by decree?

Let us be realistic in this for a moment and ask ourselves whether, under the new Food, Drug, and Cosmetic Act, the Government has power to set standards which can then, by various means, be forced upon the trade. I happen to be of that school of thought which believes the new law gives the Government just such powers. The Government can go ahead and, after investigation, propose certain standards. The Government proposes such standards and submits them to the trade; the trade thinks they are pretty good; finally, after consultation, accepts them. From then on, with the force of law, a standard can of tomatoes will be a can which contains merchandise which, on a minimum, is thus and so. We choose to call that grade "Standard", the Government says that it is "Grade C". This particular standard that has been set for the quality of the merchandise meeting such and such specifications has got to be called something; the Government says that is "Grade C."

What will Mrs. Consumer call it? This depends, it seems to me, upon the degree of educational pressure to which the consumer is exposed. And if that holds good for quality, it likewise holds good for quantity, for size of containers, for variety of containers.

We definitely favor a general cutting down in the multiplicity of cans, of can sizes, and of containers as a whole. The tall and the short, the half number and the full number, the odd-shaped bottle and the false-bottom bottle-devices which savor more or less of confusion, to say the least, in the minds of the packers and distributors, and may quite easily be used for something more sinister than mere confusion in the minds of consumers. The result is total inability of smaller merchants to stock varieties available, for obviously the small man with small capital cannot possibly have a so-called "full line" when the line consists of 40 different sizes of containers for one item; but he can have a full line if we come down to 4 or 6 .

Those of us whose chief concern is the small individual store, must always bear in mind that the greater the obstacles to competitive equality between that individual merchant and his multiple-store competitor, the smaller the chances are for that small man to survive. A common-sense cutting down, therefore, of the myriad varieties, shapes, and sizes of containers, must of necessity reduce the ad- 
vantage of the man with adequate capital, as against the little business man who has a hard time to scrape up enough money to meet his weekly bill. He simply does not have the money. It may be his fault, and then again it may not be. This is not the place for a discussion of that phase of it; but the stark fact remains that he hasn't the money. If he has to attempt to stock a full line of any one commodity, which in turn means 40 or more sizes and containers, that little man is licked before he starts. The consumer may know very little about the difference between a No. 2 or $2 \frac{1}{2}$ can, and thousands of consumers perhaps don't care, but the small merchant must care, for it means he either has to double his stock of merchandise "to be competitive," or else be at the mercy of the man who can offer the No. 2 can at a consistently lower price. Actually, if we should continue the present number of containers, which total over 150 different sizes, it is conceivable that through the careful manipulation of this one thing alone, more and more trade can be directed into certain channels, to the grave danger of the small man on the corner.

To us, therefore, the simplification of the variety of sizes, containers, and packages becomes a serious consideration. We believe that the whole question is tied up with the problem of proper consumer education, which involves descriptive labeling as well as intelligent packing, packaging, and standardization of size and type.

It involves, from our point of view, perhaps a National educational campaign the like of which the industry has never undertaken, the like of which the American consumer might now not even want, but certainly needs. It means the putting aside of brands for the greater aim of fixing in the consumer's mind the convenience of, advantages of, and protection to her of certain standard sizes; the next step then will be certain quality standards; and the third will be the classification of brand within those standards, both of size and quality.

It would be a rash person indeed who would attempt to suggest even the outlines of such a program in a brief talk of this kind. Our only contribution, if it is such, today, must be limited to bringing out into the open and onto the top of the table the possibility of a joint trade and Government program for the education of the consumer.

The interests of both not only need not, but should not, be different. Both the Government and the trade should be interested in having the consumer fully and accurately informed-not in the way of propaganda, but in the way of education and information. We shall both benefit when the consumer knows intelligently how to buy her canned goods; knows and understands the problems faced by industry as producers, by business as distributors, and by the Government as an umpire, interested in seeing to it that a minimum set of protective rules are adhered to.

We see no reason why common sense and a genuine cooperative spirit should not be able to produce this; we are fearful lest the tradeand by this we mean the producing, processing, and distributing trade as a whole-should allow itself to be blinded by individual selfinterest, and thus lay itself open to frontal attacks from both the Government and the consuming public. We shall definitely deserve such attacks, and the inevitable Government regulation which will follow, if we fail as intelligent businessmen to come together for a common purpose, and evolve a common aim toward which we can march together. 
We accordingly endorse, as a splendid step forward, the efforts of the National Canners Association in cutting down the va ieties of types and sizes in the various products. We want to pledge to them our support in this effort and our cooperation toward a further standardization, if and when this is possible. In any joint effort undertaken for the purpose of adequately and accurately educating Mrs. American Consumer, you may count on us for our full share.

\section{DISCUSSION OF ABOVE PAPER}

Mr. Pisciotra. Mr. Chairman, may we be permitted to ask a few questions as we go along?

The Acting Chairman. It was my understanding there would be no discussion until after the speakers had completed.

Mr. Piscrotta. That was on the report of the Committee.

The Acting Chairman. I think that would be a good idea, in view of the fact that some of the people may leave.

Mr. Lazo. I shall be glad to answer questions, but not technical questions, because I am not a technical man.

Mr. Pisciotta. I would like to know where in the Food and Drugs Act is there a provision giving power to regulate and standardize by weight the contents in any containers.

Mr. Lazo. The consensus of opinion among the lawyers I talked to-not Government lawyers but outside lay lawyers-was that the power depended upon the degree of rigidity of interpretation of that clause which permits the Government to set standards. My conception of it is that the Food and Drugs Act gives the Government considerable latitude of power.

Mr. PisciotTa. Is there any possibility of getting the one who gave that information to enlighten us, because we have investigated and studied the Food and Drugs Act and think there is no possibility in there of regulation. I understand that before the Committee on Coinage, Weights, and Measures that very question was raised, and at that time no one was able to point to any provision to standardize containers.

Mr. LAzo. I shall be very happy to draw up and transmit to this Conference the opinions that have been given to me. I will send a consensus of them to the chairman, so that you may all have them.

Mr. Pisciotta. We would appreciate it. May I ask another question? Does your Association, representing the distributors, really know what the consumers want as to the particular sizes of containers?

Mr. Lazo. Nobody knows that.

Mr. Pisciotra. Have you made any attempt to find out?

Mr. Lazo. Yes; as much of an attempt as is possible to make under the circumstances. Quite frankly, you know and I know that there is not one out of a hundred consumers who knows what he wants; and I doubt if there is one out of fifty consumers who would be able to make distinctions between the present cans on our shelves.

Mr. Pisciotta. And it is necessary for someone to eliminate many of them?

Mr. Lazo. Yes; I agree with you, it is necessary to eliminate some of them, and it is necessary to educate the consumers as to what we have left, and why. 
Mr. Pisciotra. I believe the simplified-practice project was inaugurated in 1931. What progress has been made to simplify the containers from that time until now?

Mr. Lazo. That I would not be able to tell you. I don't think the distributors have accomplished very much, and that is the theme of my song here-that we should do more and that we are willing to do more. We have perhaps been standing on two sides of a fence, whereas we should have taken the fence down and shaken hands.

Mr. Pisciotta. Do you think one distributor out of a hundred could upset the others? If he were a big distributor of large ways and means, a powerful distributor, then he might dictate to the other ninety-nine.

Mr. Lazo. No; I don't think there is any one distributor today who can dictate to the rest of the industry.

Mr. Pisciotta. He may refuse to go along with any of themstill go along with his own activities, regardless of what the others do, and there would be no force under the law to compel him to do otherwise.

Mr. LAzo. Is it your understanding, sir, that the only force in the world is the force of the law?

Mr. Pisciotta. Is there any other force?

Mr. Lazo. Yes; I think so. We have demonstrated in the food industry there is a tremendous cooperative moral force between us, the manufacturers and distributors alike.

$\mathrm{Mr}$. PIsciotta. Has it accomplished anything in trying to satisfy this particular problem?

Mr. Lazo. Well, that has to be demonstrated. This is one problem. We are thinking of our own side of it. We are thinking primarily of the distributor or manufacturer, and this is one of many problems. This has not been tackled jointly, and it is my belief that we should tackle it. I am not in favor of doing it by Government decree. I think it can be done differently. It can be done by a cooperative approach to this thing, and I am not in favor of more law. Every law is simply a restriction upon the freedom of action or liberty of someone. That is a law. And to the extent it restricts that freedom, that law is effective. Now, I am not in favor of that. I $\mathrm{am}$ in favor of common-sense voluntary action wherever possible. We haven't tried cooperative action yet. This is a very healthy thing. We may not agree as to the method, but I think we crn agree as to the ultimate end. But this is a very healthy thing, to discuss our problems together and take some action together. And if the trade fails to come to you and fails to act cooperatively and do at least its full share-although I think you will find the trade perfectly willing: to do so - then it is time for Government regulation. I do not think this is the time for it. I have been here observing these things in. Washington for years, and I still don't believe the law is the way to do it.

Mr. Pisciotra. I understand the simplified practice agreement. was entered into about 5 or 6 years ago and hasn't been applied yet, because the largest distributors and manufacturers won't sign.

Mr. LAzo. Is that all the fault of the trade?

Mr. Pisciotra. Yes; they could get together and do it without someone forcing them to do it. They have had since 1931 to do it $218292-40-3$ 
and haven't accomplished it yet. Sooner or later somebody will have to force them to do it.

Mr. Lazo. And you think the only way is by further legislation?

Mr. Pisciotta. There is no other way.

Mr. Lazo. 'That is where we part. Here is Constitution Avenue, and here is Pennsylvania Avenue, and you come up one and I come up the other. I think we can do it voluntarily. However, I don't say we should have no regulation at all. I would be the last one to say that.

Mr. Pisciotra. The law is a regulative power.

Mr. Lazo. Yes; but there are laws and laws, and there is a certain amount of policy with the power, and to the degree we extend it, to that degree we reduce the voluntary action of the people as a whole. My plea is that we attack this as a common-sense problem first to have as much as we can of voluntary action. I don't think that you gentlemen, for example, have given us the benefit of all of your technical knowledge and experience as to how we might go about a voluntary action of that kind. If you have, then we have fallen down, and perhaps you should let us see if there isn't another chance. If there isn't another chance, I am here to tell you we are going to have Government regulation, and I know it and you know it, and I want to avoid it. And if we fall down and don't do it, we are going to get Government regulation and have asked for it.

Mr. PisciotTa. What cooperation have you seen from the industry?

Mr. LAzo. Well, I am not entirely in agreement that it is always industry that is at fault. And I am not one of those that says everything the Government does is wrong. Far from it. I think we must approach this thing from both points of view. You come part way and we come part way. Perhaps we haven't come far enough. We are hanging back on the side line, perhaps we are hanging back too far. All right, let us make a common-sense approach toward meeting half way. Let us do that, and then if we fail, all right, and we have then simply to ask the Government to come in and force us to do it.

Mr. Pisciotta. Have you read the recommendations of the committee?

Mr. Lazo. Yes, sir; I have read the recommendations of the Committee, and I am a bit fearful that the main thing there, so far as I have been able to interpret it in the few minutes, is more Government regulation. And I am just simply pleading with you to see if we cannot do it through cooperation first.

Mr. Pisciotta. In other words, you want one more chance?

Mr. Lazo. Well, let us say, let us give each other one more chance?

Mr. Pisciotta. All right.

Mr. Kanzer. Mr. Chairman, may I ask just one question, please, of the speaker? Let us assume all manufacturers and distributors of tea, except one, want to have a 1-pound package of tea; that one wants a 15-ounce package of tea. What method could we pursue to pull him in line?

In the State of New York, the sale of ice cream was being made in the odd-sized containers. We passed legislation in cooperation with industry, because the different dealers would not all pull together. Would not you say that the only answer in such case is Government regulation? 
Mr. LAzo. I am afraid I agree with you. If we cannot bring ourselves into line, then we are going to have Government regulation. I was rather hopeful there would be more people of the industry here today because it is to them I am talking. I have been preaching this for several years. I don't think we are going to solve it simply by slapping in an over-all law, Federal or State. I think there is much that can be done.

I had considerable to do with regulations under NRA in the food industry, and I am perfectly willing to be quoted for the record as saying to you that $991 / 2$ percent of the cooperation and of compliance there was voluntary. We do have those who don't do what they should do, including judges, and that is why we have laws and jails. I cannot say it should not be done by legislation if it cannot be done otherwise.

The Acting Chairman. I think Mr. Lazo has given us a very good expression of the viewpoint of the retail food distributors on this question. We certainly wish to thank you, Mr. Lazo, for coming here and giving us this expression of your viewpoint.

\section{PAPER PRESENTED BY CARLOS CAMPBELL, DIRECTOR OF THE DIVISION OF STATISTICS, NATIONAL CANNERS ASSOCIATION}

Mr. Chairman, ladies, and gentlemen: The need for standardizing containers for canned foods is well-recognized by the canning industry. It is, however, a relatively easy matter to recognize the need for a change, but quite another problem to prescribe a satisfactory method for making it. No reputable physician would attempt to prescribe a remedy without a diagnosis. We have recognized certain symptoms in this case, but as yet a thorough diagnosis involving the various ramifications of the problem has not been presented. (When I say it has not been presented, I am not referring to any discussions that have taken place here at this Conference. This paper was written before.) The first step in making a diagnosis is, of course, to obtain the facts regarding the history of the case.

The canning industry in the United States is approximately 100 years old. It has grown up in many parts of the United States, each section being developed more or less independently of all others. Foods are canned in all but two of the States. It is only natural that various types and sizes of containers would be developed.in these various sections, partly because of the different types of products being canned and partly because there was no coordination in the development of the industry. In this respect, however, the history of the industry's container problem does not differ from the history of the development of baskets, boxes, hampers, barrels, etc. that were used to pack fresh fruits and vegetables.

There is, however, one fundamental difference between the tin can as a container for canned foods and the dry measure container for fruits and vegetables. This difference lies in the fact that a canned food when processed must be placed in a container that carries the food all the way from the canning factory to the consumer's kitchen. Baskets, barrels, boxes, crates, etc. are containers used primarily for the convenience of the distributing trade. The size of these dry measure containers is not determined by the individual consumer's demand. Baskets of apples, sacks of potatoes, crates and hampers of 
fresh vegetables, are delivered to the retailer, who sells their contents to the consumer in broken lots of many sizes.

It isn't possible for the retailer to sell canned foods by cutting a No. 10 can and parceling out to his consumers so many ounces or pounds. Because of this characteristic it has been necessary for the canner to study the nature of the ultimate consumer demand and to try to predict the amount of food which the ultimate consumer would care to purchase under all the various conditions that affect the demand for food. The variation in the size of families, consumer purchasing power, prices, geographic differences in native food habits, differences in classes of consumers, and many other factors could be mentioned that tend to cause consumers to purchase foods in varying amounts.

Anyone who has had experience selling to the retail trade knows that consumers' tastes and the amounts of individual purchases vary widely. $\mathrm{He}$ also knows that these variations are frequently not predictable. Knowing these facts, the canner has attempted to satisfy the consumer by making available to her a wide variety of can sizes from which she can choose.

It isn't possible for any one canner, or hardly feasible for any group of canners, to obtain from all the consumers the size of containers in which they would like to purchase their canned foods. In actual practice this information has been obtained by what might be termed the trial and error method; that is, a canner starting out to pack a new product packs it in as wide a range of sizes as is economically practicable, but he continues to pack in only those sizes which the consumer purchases. Therefore, at any particular time the vast majority of the can sizes that are used in the industry are being used because those are the sizes which the canner has found the consumer buys.

One might expect that over a period of time canners would have determined the can sizes which consumers want, and that the industry would settle down to these sizes. This result could be expected only if conditions were static. Everyone knows conditions are changing from day to day. The sizes which a canner found were acceptable to his trade last year may not exactly suit the situation this year. For that matter, we have observed radical shifts in consumer purchases of various can sizes within a given marketing year. That occurred this year very definitely. Furthermore, new products are being developed and with each new product there is a separate problem of determining the can sizes that consumers desire.

Canned foods are not a homogeneous product. The industry cans over 200 products, each product having its own consumer appeal and each product having certain physical characteristics which affect the size and shape of container required for processing. This necessitates considering each product separately. Certainly no one would expect consumers to purchase tomato paste in only the size of cans used for tomato juice or canned tomatoes. The aggregate number of can sizes used by the canning industry should, therefore, not be considered without due regard to the number of products for which each of these can sizes is used.

The National Bureau of Standards, in cooperation with the National Canners Association, made a survey of the canning industry last year to determine the size of the pack of each product in each of the various 
can sizes used. The cooperation which canners gave this study is worthy of comment. About 96 percent of the total pack of fruits and vegetables was reported in this survey.

The number of products covered depends entirely upon the definition of a product. The classification made in tabulating the data combined a number of products under one heading, when the physical characteristics of the products would permit their being packed in the same can sizes. In spite of this method of classification, the tabulation included 101 separate and distinct products. These products were canned in can sizes which in the aggregate totaled 155.

Products such as corn, peas, tomatoes, green and wax beans, which taken together represent close to half of the total pack of vegetables, were canned in a relatively small number of can sizes. These products, however, have been canned for many years, and canners have had an opportunity to determine fairly well the sizes that consumers want. On the other hand, tomato juice, a relatively new product, was reported in 44 different can sizes, which quite obviously represents a far greater number than is necessary. But this illustrates the extent to which canners cover the entire range of can sizes in their attempt to determine which sizes the consumer will buy. Even though tomato juice has been packed for a relatively short period of time, the industry has already discarded a number of sizes that were tried out in the beginning. In 1937, of the 44 sizes reported, each of 16 were being used by one canner only. Many of these cans did not appear in the 1938 pack.

If given time, can sizes for eacb of the products would tend to become standardized through the operation of the economic laws which govern the sale of a canned food to consumers. The objection, however, to this process of standardization appears to be that it takes too long. The remedy is to accelerate the standardization process, that is, speed up the natural processes that lead to standardization. It would be a grave mistake not to recognize the dynamic nature of consumer demand for canned foods and to freeze the size of containers on the basis of conditions at any one date.

The canning industry, appreciating the problems involved, has developed a program to bring about a more speedy standardization of containers. This program has two main objectives: (1) The elimination of sizes which because of closeness to other sizes might be confusing to consumers, and (2) sufficient elasticity to take care of changing consumer demand and improvements in canning operations.

The data on the 1937 pack have been studied very carefully for the last nine months by the Association's Committee on Simplification of Containers. The Committee, consisting of canners of long experience who realized the magnitude of the problem, analyzed it first from the standpoint of what had been done in other industries. Before any attempt was made toward selecting a list of can sizes, the Committee drafted a set of principles which would govern the selection of sizes.

The first principle adopted was that, because of the differing physical characteristics of the products, and because of the differing consumer demands for the various products, it was necessary to select a list of can sizes for each product. Any one who is familiar with the problems of canning and selling canned foods would, I an sure, agree that this principle is fundamental. 
As a matter of fact, this principle is not new. Standardization of dry measure containers for fruits and vegetables was approached on a commodity basis, with successive laws enacted for different products. It is now proposed to consolidate the existing laws, but in this consolidation the principle is retained, and it is not proposed to set up a single list of dry containers of one specified type that must be used for products of different types.

The Association's Committee fully appreciated the fact that, if a list of sizes were selected for each of the principal products and these lists were then combined and canners permitted to use any of these sizes for any or all of their products, there would very probably be as much confusion as before standardization was attempted. For eximple, a $307 \times 508$ can was selected as one needed for packing corn on the cob, but its use for other products could very easily cause confusion among buyers. Accordingly, the Association's Committee recommended a separate list of can sizes for each of 58 different products. These recommended lists have been approved by the Board of Directors of the National Canners Association, and the Board at its meeting May 18 made formal request of the National Bureau of Standards to revise its simplified practice recommendation for the canning industry by adopting these lists of cans.

The 58 fruits and vegetables included in this program were so classified as to cover the principal fruits and vegetables packed in the industry. The total pack of these 58 products amounted to about 97 percent of the total pack of all fruits and vegetables in 1937. The remaining 3 percent of the pack was not included in this standardization program because of inadequate data. The inalusion of these other products is contemplated as soon as possible.

The 58 lists of can sizes recommended include 45 sizes in the aggregate. This represents a substantial reduction from the 155 sizes used in 1937. Each of 27 sizes was recommended for one product only, thus emphasizing the peculiar requirements of individual products. Eighteen sizes were recommended for more than one product. The output of products in 1937 for which these 18 sizes were recommended totaled about 90 percent of the total pack of fruits and vegetables. Thus, only 7 percent of the total pack will be permitted to use sizes not included in the list of 18 sizes.

For a number of products only three or four can sizes have been recommended. Canned tomatoes have only four sizes, peas and corn (not including corn on the cob) are allowed six sizes each. These three vegetables represent about 40 percent of the total pack of canned vegetables. For other products, however, a larger number of sizes was selected. Asparagus and tomato juice each have 10 sizes, this being the largest number recommended for any one product. Of the 10 sizes recommended for asparagus, 3 are permitted for no other product.

In the case of tomato juice, although 10 sizes have been recommended, it should be recalled that 44 sizes were included in the list from which these 10 were chosen. In the case of a juice product, there is apparently a greater demand for cans of varying sizes. But, as previously stated, tomato juice is a relatively new product, and it is practically impossible at this time to fix a list of sizes that will be satisfactory for all time to both canner and consumer. In other words, the program contemplates some modification in the list of sizes selected 
for tomato juice and certain other products, keeping in mind, of course, the two principal objectives previously stated.

In the case of beans with pork or sauce, 25 sizes were reported as used in 1937. The recommended list includes 8 sizes only. These sizes range from the $8 \mathrm{Z}$ Tall, $211 \times 304$, having a minimum volume fill of 7.47 fluid ounces (8 ounces avoirdupois) to the No. 10 can, $603 \times$ 700 , having a minimum fluid ounce fill of 94.59 ounces ( 6 pounds 12 ounces avoirdupois). The first seven of the eight cans listed for beans with pork or sauce are primarily for the retail trade, the No. 10 can being principally for wholesale or institution buying. Of the seven retail or shelf sizes, the minimum spread in net capacity is 3 ounces whereas the maximum is 4 ounces.

The criterion of what constitutes confusion in buying is not in all instances the spread between the capacities of any two cans. The shape of the can needs to be taken into account also. A fixed difference in capacities could not be used as a criterion, because a small difference in small cans might not be as confusing as a larger difference in large cans. Furthermore, any criterion that is adopted must be applied on a practical basis, that is, if the bulk of the sales of any given product has been in medium-sized cans, the Committee felt that it was desirable to make available to the consumer a relatively larger choice of cans in that group than in the smaller or larger cans. This practice tended to make the spread in capacity smaller for the more popular cans and wider for the less popular ones. This principle is considered sound, especially in view of the fact that canned foods are sold on a net content basis, it being required by law that the net content be prominently stated on the label.

To summarize the Committee's point of view and the actions it has taken, it may be said:

The can is a container, not a measure, the size of which is determined primarily by the consumer. It performs a dual function as an original container and a consumer package.

As an original container, the can must be adapted in size and shape to the product for which it is used.

As a consumer package the can size is subject to changes that constantly take place in consumer requirements and buying habits. For this reason it is impracticable to select for permanent use a list of sizes based on consumer preference as of any given time. The Committee, nevertheless, recognized that there should be a simplification of can sizes which would prevent confusion in buying, and at the same time permit modifications that would meet the changing requirements of consumers.

The lists recommended by the Committee are based upon consumer preference as measured by sales of the respective commodities; they eliminate sizes that might be confusing to buyers.

The Committee, on behalf of the industry, has labored in good faith to work out a program that is both practical for the canner and helpful to the consumer, by giving her a visual measure of the relative amounts of food in the cans, in addition to the statement of net contents which the food law requires to appear on the label.

(At the conclusion of his paper, Mr. Campbell exhibited a chart showing can sizes in common use and the can sizes remaining in the recommended list, and commented briefly on the reduction in the number of sizes.) 


\section{DISCUSSION OF ABOVE PAPER}

Mr. Pisciotta. I believe you said at the beginning that as far as boxes were concerned, they were primarily for distribution by the wholesalers to the retailers. That is not true of grapes and strawberries, for instance, sold in boxes.

Mr. CAMPBElL. The statement would not hold true for everything, but in general it is true. Also it is possible to break these boxes without destroying the value of the product. Sometimes the contents of grape boxes are broken up and sold by the pound.

Mr. Pisciotra. Does not the size of can available dictate the particular size the consumer orders? Has the consumer any choice in the matter?

Mr. CAMpbell. I would say if there were very many sizes being sold, the consumer would have a large choice.

Mr. Pisciotta. But if a retailer carries a limited number of sizes, then what?

Mr. CampBell. One of the complaints is that the grocer has to carry too many sizes-that the choice is already too wide. So I would say that the consumer has had an opportunity to choose from quite a wide list of cans and that the number of cans of a certain size sold is a pretty fair indication of what the consumer wants.

Mr. Pisciotta. If a consumer wanted a pound of canned peaches, which she cannot get, and the next nearest size is 14 ounces, she would have no choice there.

Mr. Campbell. No, because there do not happen to be enough can sizes to permit that choice.

Mr. Piscrotta. What has the industry done to consult any consumer group to find out what is really wanted?

Mr. CAmpBell. There has been a very extensive survey made of consumers all over the United States by one of our large canning organizations to determine what the consumer wants, and the list of cans selected for the product involved is based upon that survey. It was made by the pineapple people.

Mr. Pisciotra. Isn't it true that the can manufacturer will manufacture any size and shape can that the packer really requires?

Mr. CAMPBELl. Well, I presume that is true; yes. That is usually true of any manufacturer. If it is feasible, he will manufacture the product the consumer wants. Our recommendations can place no restrictions on the can manufacturer.

Mr. Pisciotta. Do you know any reason for making this package of spaghetti $15 \frac{3}{4}$ ounces rather than 16 ?

Mr. CAMPBELl. I should say that there was no attempt to make it of a certain weight; the package was first selected and the quantity in it was the result.

Mr. Stewart. May I answer that? The chances are that the contents of that can weigh 16 ounces. We purposely dropped the marked weight to $15 \% \frac{3}{4}$ ounces to avoid any possibility of having a lot of cans that did not weigh the full 16 ounces, thus violating the old Federal Food and Drugs Act. We could not be sure that every can would weigh 16 ounces.

Mr. Pisciotta. That argument holds true. In order to play safe, you mark it less? But how about the markings on bottles of milk or loaves of bread? 
Mr. Stewart. I can't answer the argument about those com modities. I am not familiar with them. But I am able to explain about that can.

Mr. KANZER. If that were true, why is it that the marked weight on a half-pound can of salmon has fallen from 8 ounces to $7 \frac{3}{4}$ ounces, and again, to $7 \frac{1}{2}$ ounces?

Mr. Stewart. There are two sizes of can. Columbia River salmon is the kind you will find more frequently labeled $73 / 4$ or $7 \frac{1}{2}$ ounces, while the Puget Sound salmon can will hold a half pound of salmon and is always labeled $73 / 4$ ounces.

Mr. Kanzer. If you try to cover yourself with a quarter of an ounce, why take another quarter of an ounce and get down to the $71 \frac{1}{2}$ ?

Mr. Stewart. That Columbia River salmon is packed in a smaller can than the Puget Sound salmon.

Mr. BAUCOM. May I say this, that your statement indicates that you are knowingly and willfully misbranding your product.

Mr. Stewart. In order to be safe the trade labels a fraction under the content of the can.

The Acting Chairman. I would like to suggest that, so far as it is possible, this general discussion of the subject be withheld until the speakers have all had an opportunity to express their views.

Mr. O'K Eefe. Mr. Chairman, I do not think that is right. I think that since some of these gentlemen may have to go away, the general discussion should be held right here and now.

The Acting Chairman. I am certainly agreeable to a thorough discussion as we go along, if that is agreeable to the membership.

Mr. Kanzer. Mr. Campbell suggests that the number of cans was initiated and determined by the consumers. If that were true, then his argument would be more or less sound, but I wonder if that is completely true. It seems peculiar that every time the consumer wanted less in his package than the standard size, irrespective of the size of the family. It would occur to me that the canning industry found themselves up against the difficulty presented by the man who found he could put out a can that would simulate the standard size. When he took the quarter of an ounce off and got away with it, the next man took off the next quarter ounce. With this there came to be a series of packages and cans that confused the situation. The industry has raised its own Frankenstein; now they are seeking relief as much as we are trying to help them get that relief.

Mr. CAMPBELL. Well, in the first place, if you will read my remarks you will find I didn't say the consumer initiated the size of the package. The canner, in order to find out by the trial and error method what the consumer wants, starts out packing a wide range of sizes, which in the case of tomato juice in 1937, was 44 . But he continues only those sizes he can sell. Why can he sell them? Because the consumer buys them. Thus the consumer tends to determine the size of the package. It has been suggested that possibly the consumer doesn't have a wide choice. There may be some argument to the effect that the fact that even though the consumer buys a certain size this does not represent the consumer's choice. Well, I think that the consumer has had a wide enough choice of cans from which to purchase to enable the canners to determine which ones the consumer prefers.

Now your point, as I understand it, is that the consumer might prefer a size of can which is not being packed. 
Mr. KANZER. That was exactly my point. It seems strange that all of these sizes developed are short of the standard size and not above the standard size.

Mr. Campberl. There were no standard sizes.

Mr. Kanzer. I refer to sizes holding 1 pound, 8 ounces, and so forth.

Mr. Campbell. Well, we are packing in the industry some 250 different products. It is not feasible to have a can size which will produce 16 ounces avoirdupois of each one of these products without having thousands of sizes. If you will take a size holding 16 ounces of one product and use it for another product you are not going to get 16 ounces.

Mr. KANZER. It seems strange that one of those sizes should not be above as well as below what we consider the standard size.

Mr. Campbill. We have cans that go over the 16 ounces, as well as those that go under.

Mr. KaNZER. What proportion would you say would be over 16 ounces?

Mr. CampBell. There is a greater percentage over. Today the No. 2 can is most widely used. This usually contains 2 ounces, approximately, over 16 ounces, and in some products 3 ounces; it depends upon the product.

Mr. Kanzer. I think you will agree with me that the No. 2 can started out as a 2-pound proposition; for instance, rolled oats and lard in 1912 in this size always weighed 2 pounds net. It later became 2 pounds, including the can, and now it is anywhere from 1 to 2 pounds.

Mr. Campbell. I don't know the history of the No. 2 can far enough back to say whether or not it ever held 2 pounds. The No. 2 can has been erroneously referred to as a 2-pound can. To what products do you refer?

Mr. KaNzER. I will put it generally. Specifically a No. 2 can of lard, contained 2 pounds. The No. 5 can was always 5 pounds of lard net; then the 5 pounds included the weight of the can; now it has dwindled, as has the No. 2 can.

Mr. Campbelis. You understand, of course, the can used for canning fruits and vegetables is not the can used for lard.

Mr. KANZER. The weight of the contents of the No. 2 can of canned goods has dwindled considerably and now No. 2 is a designation and has no reference whatever to any weight. But the point is this, you maintain you want a number of sizes. In this committee report there are 14 sizes provided, from 0 to 1 quart. You spoke of having 10 sizes in the case of canned tomatoes. Those 10 sizes are spread over a short limit. We provide for 14 sizes, and they are all standard sizes; certainly we have enough between 0 and 1 quart to satisfy the average requirements of the consumers, be they individuals or families.

Mr. Campbell. The 14 sizes you refer to range from 0 to 1 quart; the 10 sizes I referred to were for tomato juice, and they are spread from 6 ounces to 100 ounces.

Mr. KANZER. Well, I don't know just exactly what you have there. But the Committee report provides enough sizes for the canning industry, and certainly they will be guided a little bit by the consumer's choice. 
Mr. Campbell. Those 14 sizes you refer to, I think you will find in this recommended list. In our program there are only 18 sizes recommended for more than one product. Consequently, the number of can sizes you refer to and the number we have recommended are not very different.

Mr. Kanzer. Well, they are different, in the sense that those you recommend are not of the standard capacities. No customer goes in to buy an odd number of ounces of anything; yet when you ask for a quart or pound, you get an odd size.

Mr. CAmpbell. The question was asked of me what we have done to find out what the consumer wants to buy. There has been one very extensive survey. Let me ask the same question. What have you done to find out what the consumer wants to buy of canned foods?

Mr. KaNZER. I don't think we should put it that way. We have made no survey. We do know that the customer does not go into the store and ask for an odd capacity or odd size. We don't need an investigation on that.

Mr. Pisciotta. May I answer that question? We have had numerous complaints from people who ask for a pound of something, and who discover a label of 15 or 14 ounces, on the article furnished. In order to check, we have sent inspectors out to retail stores asking for a quart of a particular commodity; 90 percent of the time he was given 29 ounces instead of 32 ounces. The retailer, in practically every instance, insisted he has handled that particular object for years and years and always was under the impression that the bottle held a quart. We have followed very many commodities, and gradually from time to time have found packages reduced to 15 ounces, to $141_{2}$ ounces, to 14 ounces. That is how we found out what the consumer asks for and expects when he goes in to buy, and what he is getting. The retailer himself, objects, so much so that the Retail Customers Board of the City of New York, Brooklyn, and Jersey City, has gone on record in favor of even standard weights, doing away with the 14-, 15 -, and 151/2-ounce sizes, and keeping the 16- and 12-ounce sizes.

Mr. Campbell. Don't you see, Mr. Pisciotta, that it is impossible to standardize on 16 ounces and at the same time standardize can sizes? If you are going to give 16 ounces always, of 250 different products, you are going to need different size cans to give 16 ounces of the different products.

Mr. Pisciotta. Suppose you do: What of it?

Mr. Campbell. Weil, it would lead up into thousands of can sizes.

Mr. Pisciotta. Let us see this example here. I have three cans of three different commodities-one is soup, one is sweet peach, and one is asparagus. One size of can would hold 12 ounces of each. Isn't that true?

Mr. Campbell. No; different cans would be needed; one size would not have the same net weights.

Mr. PisciotTa. These cans are of one size; each is labeled $101 / 2$ ounces. We have opened them and found the contents to be correct.

Mr. CAMpberl. In that case, they are peculiarly accurate.

Mr. Pisciotta. Here are two cans of the same dimensions [indicating] of different commodities each containing 1 pound, 14 ounces. If the standardization was made to 16 ounces, at least these two would use one can. So that you wouldn't have 250 cans for the same weight. 
Mr. CAMpBell. You would have thousands of sizes for the various weights of the various commodities. Take peaches alone; you have a great many packs of peaches, and no two have the same specific gravity, so that for the given weight you would have different sized cans for those different grades of peaches.

Mr. Pisciotta. As far as liquid measure is concerned, the size is regardless of the commodity.

Mr. Campbell. Yes. But in order to standardize on a given weight, you would generally have to have a separate can for each separate product or grade of products, although some different commodities could probably be packed in the same size.

Mr. Stewart. Mr. Kanzer, what canned fruits or vegetables put in a No. 1 can weighed 1 pound, or in a No. 2 can weighed 2 pounds?

Mr. Kanzer. Generally all No. 2 cans weighed 2 pounds.

Mr. Stewart. What were the products?

Mr. Kanzer. I cannot tell you now. I will have to check on it.

Mr. Stewart. I have been in this business for 30 years and never in my life have I seen any No. 2 can of fruits or vegetables which weighed 2 pounds. I wanted to have this on the record, because if you will look over this list of weights as published by the Canners Association you will find that the No. 2 can ranges for various commodities anywhere from 1 pound and 2 ounces up to 1 pound and 6 ounces. Back in the year 1900, there were three cans for fruits and vegetables-the No. 1, what we called 1 pound at that time, the No. 2, and the No. 3. Now, when the Federal net-weight law went into effect we weighed those cans and we never found one that weighed 2 pounds.

Mr. Kanzer. Did it weigh 1 pound and 2 ounces at that time?

Mr. Stewart. They weighed about that weight; yes, sir. When the sanitary cans came into existence, they were made to approximate, as closely as possible, the capacity of the old cans.

Mr. KanzER. I can say very definitely-and you have just agreed to it - that the No. 2 can back in 1912, meant 2 pounds, as far as the people were concerned.

Mr. Stewart. We called it that, but you show us some that weighed it.

Mr. KANZER. I would say the No. 2 can generally contained 2 pounds. I will check back and send the information to you. I am very much pleased at Mr. Campbell's answer to Mr. Pisciotta, that there was no difficulty with respect to capacities. If there is any question in reference to weight, there apparently is no question in reference to capacity.

The Acting Chairman. There is a motion to proceed with the program. I want to express to Mr. Campbell our appreciation of the discussion he has given us on this subject from the viewpoint of the canners.

PAPER OF ARTHUR P. WILLIAMS, PRESIDENT, R. C. WILLIAMS

AND CO., REPRESENTING THE NATIONAL-AMERICAN WHOLE-

SALE GROCERS' ASSOCIATION ${ }^{1}$

This memorandum is submitted in behalf of the members of National-American Wholesale Grocers' Association, who distribute a large percentage of the wholesale grocery volume of the United States.

1 In the absence of Mr. Williams, this paper was presented to the Conference by M. L. Toulme, secretary. Notional-American Wholesale Grocers' Association. 
The members of the Association, located in every State of the Union distribute thousands of different kinds and types of food and grocery products.

Wholesale grocers distribute a wide variety of food products in package form purchased from many manufacturers and packers scattered throughout the United States and in foreign countries. Many of the products distributed by wholesalers are purchased in bulk and then processed, conditioned, packed, and distributed under the labels, trade-marks, and brands of such wholesale grocers. Millions of dollars have been spent in the development of goodwill in these labels, trade-marks, and brands that now are well known to consumers of this country.

The National-American Wholesale Grocers' Association was organized in August 1933, as the result of the union of National Wholesale Grocers' Association and American Wholesale Grocers' Association; the organization having been accomplished in order to facilitate operations under the National Industrial Recovery Act and the NRA Codes.

Distributors of food products have much in common with Government and consumers in the weights and sizes and shapes of food containers of all types. Unnecessary multiplicity of sizes, weights, and shapes of containers forces distributors, vitally interested in the costs of doing business, turn-over of stock, and the competitive situation, to invest undue amounts in stocks.

Throughout the years, trade associations of distributors in the food field have wrestled with this problem. At the start, it was thought by many food distributors that the problem could be solved without undue economic dislocations and unfairnesses, by simple statues, compelling regularity, uniformity, and simplicity. However, the more the facts are studied and weighed, the more complicated reform becomes. The lists of food products, canned and packaged, are already long and are constantly being lengthened. Nature is whimsical and even stubborn about producing differing sizes and shapes of food products. Legislators as well as distributors may propose uniformity and standardization of containers, but nature seems to be uninterested in duplicating the reforming of sizes and shapes of her products. A willful Nature also complicates the food situation further by producing feasts one year and famines the next, thus dictating wide fluctuations in prices, and prices control consumer buying habits mightily, as all producers and distributors will testify. Millions of consumers, scattered over the face of the earth, also have their own ideas, prejudices, needs, and preferences, depending upon where they live, how they live, and the sizes, tastes, and incomes of their families.

Once there was an old giant who had his own ideas and convictions about the desirability of regularity, uniformity, and simplicity. However, his hobby concerned weights, sizes, and shapes of men. Naturally, he was convinced that men should be large, tall, and handsome, like giants. This giant freely invited stranded wayfarers to enjoy his hospitality overnight and automatically assigned them to a room in which there was a large bed.

If it happened that a particular guest was short and stout, the giant had machinery which during the night stretched the guest to a size to fit the giant's bed. If it happened that the visitor was too lean and lank, the old giant took care of that situation by cutting enough 
off of that guest, so that he fitted the bed perfectly. The giant's methods were effective, but few of his guests survived the ordeal.

Despite our natural impatience with the multitude of sizes, shapes, and types of food containers, we sincerely urge that whether we be consumers or officials or distributors, we keep before us the actual complications ahead and make progress, slow but sure, by exercising tolerance, common sense, and good judgment.

One of the objects of the Association, functioning through its Economy Conference Committee, is to participate in trade conferences under the auspices of the United States Department of Commerce with producers, manufacturers, wholesalers, retailers, and others, in order to bring about simplification and standardization of manufacturing machinery and methods in the food trade, to the end that food products may be distributed with the greatest economy to merchants and consumers. The activities of the Association and its functions in this field are described briefly in "Trade Association Activities" issued in 1927 by the Bureau of Foreign and Domestic Commerce, at page 250, as follows:

The National Wholesale Grocers' Association represents approximately 50 percent of the total number of eoncerns engaged and transacting probably 75 percent of the total wholesale grocery sales of the country.

In cooperation with the Bureau of Business Research of Harvard University it has made annual studies of costs of doing business. Its canners' conference committee confers with canners and brokers on questions having to do with the promotion of sales of canned goods and the purity and wholesomeness of such merchandise. It endeavors to suggest uniform, clear, and equitable forms of contracts for the purchase of commodities, with the aim of preventing sales litigation.

Its economy conference committee conducts trade conferences under the auspices of the Department of Commerce of the United States with producers, manufacturers, wholesalers, retailers, and other merchants for the purpose of standardizing and simplifying the sizes, manufacture, operation, and distribution machinery and methods.

Its general education committee disseminates information concerning the service of the wholesale grocer. It cooperates with Federal and State departments in the enforcement of pure food laws, with the Department of Commerce in simplification and standardization work, and since 1906 has studied State and Federal legislation and has supported measures to prohibit all adulteration and misbranding of food, designed upon the basis of uniformity with the Federal Food and Drug Act of June 30,1906, in the statutes of the respective States. Its studies include railroad service and rates, uniformity of laws on commercial subjects (particularly pure foods), and arbitration of commercial disputes.

It is recognized generally in the wholesale grocery field that there is genuine economy in the simplification of food containers, principally through reduction in the number of unnecessary sizes of containers. While recognizing that there are material savings through simplification, and that simplification promotes not only economy but also efficiency in distribution, it should be borne in mind that there is a considerable difference between simplification and rigid standardization of packages which would permit the use of only certain sizes and types of packages.

The establishment of a limited number of so-called "standard" packages not only would result in unnecessary hardship on the packers and distributors of food products, but it also would deprive consumers of various types of packages for which there is a real demand.

This Association takes the position that simplification of package sizes, rather than rigid standardization, should be brought about by 
voluntary agreements made in cooperation with the United States Department of Commerce, National Bureau of Standards, under the auspices of its Division of Simplified Practice.

The records of the Department of Commerce disclose that this Association and its members participated in simplified practice conferences for a number of years, and that they have aided materia ly in the reduction of can and glass container sizes in the interest of the public and of the trade.

This Association's representatives at the general conference with respect to cans for fruits and vegetables included:

Haas-Lieber Grocery Co., St. Louis, Mo.,

Daugherty \& Co., Pittsburgh, Pa.,

Francis H. Leggett \& Co., New York, N. Y.,

Seeman Brothers, New York, N. Y.,

Griggs, Cooper \& Co., St. Paul, Minn.,

Morey Mercantile Co., Denver, Colo.,

Oakford-Fahnestock Co., Peoria, Ill.,

Wm. Edwards Co., Cleveland, Ohio.,

Steele, Wedeles Co., Chiçso, Ill.,

Sprague, Warner Co., Chicago, III.

R. C. Williams \& Co., New York, N. Y.

Deceptive and Slack-Filled Packages.-The National-American Wholesale Grocers' Association consistently and constantly has condemned slack-filled and other types of deceptive packages in the food industry. The Association has advocated the enactment of legislation to eliminate such practices from the field, and it favored enactment of the measures introduced in Congress by Representative Haugen in 1927, 1928, 1929, 1930, and 1931 .

In addition, the National-American Association endorsed and favored enactment of Senator Copeland's bill which became the Federal Food, Drug, and Cosmetic Act of June 25, 1938. That statute specifically provides that food shall be deemed misbranded if its container is so "made" as to be misleading. Food also would be deemed misbranded if the container is so "formed" or so "filled" as to be misleading. These provisions are contained in section 403 of the act, reading:

Section 403 . A food shall be deemed to be misbranded *** (d) If its container is so made, formed, or filled as to be mislesding.

The intention of Congress in enacting these provisions is expressed clearly by the following language in the reports ${ }^{2}$ of the Committee on Commerce:

This is intended to reach abuses which have arisen in the packaging of food through the use of deceptively shaped, formed, or colored containers. It is likewise intended to reach deceptive methods of filling-particularly those known as "slack filling"-where the package is only partly filled and, despite the declaration of quantity of contents on the label, creates the impression that it contains more food that it actually does.

The new statute, shortly to become effective, prohibits, among other things, the introduction or delivery into interstate commerce of any food that is adulterated or misbranded (section 301); and, as has been indicated, the act provides that a food shall be deemed to be misbranded "if its container is so made, formed, or filled as to be misleading" (section 403). These sections are directed at the very practices that this Conference seeks to eliminate.

2 (Reports of Senate Committee on Comraerce to accompany S. 2800, March 15, 1934; S. 5, May 13, 1935 and S. 5-74th Congress.) 
Under the provisions of the act of June 25, 1938, therefore, the Secretary of Agriculture has authority to proceed against the use of containers that are so made, or so formed, or so filled, as to be misleading.

The Federal Trade Commission.-On March 21, 1938, President Roosevelt approved S. 1077, generally known as the Wheeler-Lea Act. That statute considerably broadens the provisions of section 5 of the Federal Trade Commission Act. The section originally condemned unfair methods of competition in commerce; but, as amended, the act now declares unlawful not only unfair methods of competition in commerce but also unfair or deceptive acts or practices in commerce.

Section 5 of the act, as amended by the act of March 21, 1938, provides:

Sec. 5. (a) Unfair methods of competition in commerce, and unfair or deceptive acts or practices in commerce, are hereby declared unlawful.

The Federal Trade Commission long has condemned the use of deceptive containers. Its policy in this connection is stated in the annual report of the Commission for the fiscal year ended June 30, 1938, at page 72, as follows:

Imitating or using standard containers customarily associated in the mind of the general purchasing public with standard weights or quantities of the product therein contained, to sell the public such commodity in weights or quantities less than the aforementioned standards, with capacity and tendency to deceive the purchasing public into believing that they are purchasing the quantities generally associated with the standard containers involved, and/or with the effect of so doing, and with tendency to divert trade from and otherwise injure the business of competitors who do not indulge in such practices and/or with the effect of so doing to the injury of such competitors and to the prejudice of the public.

The Federal Trade Commission has ample authority under the new statute to prohibit the use of deceptive containers in the food industry.

Canners' Viewpoint Endorsed. - At this Conference the National Canners Association has presented its views with respect to standardization of canned-food containers. A substantial percentage of the packaged food products distributed by wholesale grocers is packed in cans. The growth of the canning industry in recent years has been exceptionally rapid and new products constantly are being added to the list of canned foods. It has been estimated that canning "is a billiondollar industry." Many wholesale grocers distribute a wide variety of canned food under their own trade-marks, brands, and labels. If arbitrary, rigid standards for containers were to be adopted for canned goods, tremendous losses would be sustained in the wholesale grocery industry through the destruction of plates, labels, machinery, and containers.

The National-American Wholesale Grocers' Association endorses the views of the National Canners Association as presented at this Conference.

Conclusions.-It is respectfully urged:

First: That the Committee of this Conference make further study of, and give further consideration to, the questions involved here in view of the enactment of the Federal Food, Drug, and Cosmetic Act of June 25, 1938, and particularly the provisions of sections 301 (a) and 403 (d) of that act.

Second: That this Conference and its Committee cooperate with the United States Department of Agriculture in bringing about the enforcement of the new Federal statute. 
Third: That the work of the Department of Commerce in the simplification field be continued through voluntary cooperation of the various trades involved with the Department, in order that efficiency and economy may be promoted in the industries and that buying may be facilitated for the consuming public.

Fourth: That the Committee of this Conference renew on a vigorous and widespread scale the educational campaign among consumers urging them to make it an invariable practice to "Read the Label."

The Acting Chairman. Mr. Toulme, I thank you for coming here today.

\section{DISCUSSION OF ABOVE PAPER}

Mr. Pisciotta. Mr. Toulme, we are back to boxes, now, and away from cans. Is that right?

Mr. Toulme. We handle both, the canned foods and the packages.

Mr. Pisciotra. We have here (indicating) two boxes of pea beans, the same product, the same-sized box, the same commodity packaged by the same people. They have a 1-pound content in one box, 14 ounces in the other. Do you know any reason for it?

Mr. Toulme. In order to get it to the consumer at a price approximately what she has been used to buying it for. I don't know whether that is justified by current market conditions, but I do know, particularly in a rising market, that you do get those gradual fluctuations in the size of the containers.

Mr. PiscrotTa. In other words, if the market so fluctuates that the peas and beans become cheaper, it is probable you will go back to 15 or 16 ounces?

Mr. Toulme. It is a competition matter.

Mr. Pisciotta. Is there a standard price all over the community?

Mr. Toulme. It depends where you buy it.

Mr. Pisciotta. So then the price question does not control the contents of the box, does it?

Mr. Toulme. As far as the manufacturers' original sale is concerned, it did control.

Mr. Pisciotta. Is it possible that at some time the 1 pound sold at a price and when it was reduced to 14 ounces it sold at the same price?

Mr. Toulme. If the commodity has gone up sufficiently. If the consumer is used to a price, they may try to keep it at that price.

Mr. Pisciotta. Your sugar is still packed in standard 1-, 2-, or 5 -pound packages. Has the price of sugar changed?

Mr. Toulme. Yes.

Mr. Pisciotra. And the customers that buy sugar have to pay a penny or two cents more, according to the current price?

Mr. Toulme. I doubt that, in packaged sugar; the fluctuation is wider in bulk, I would say, than in packages.

Mr. Pisciotta. There is no regular American coffee that has been reduced a quarter or a half ounce below 16 ounces. Has there been a change in price of coffee, too?

Mr. Toulme. There has not been a rise upward. I don't believe the fluctuation has been enough to bring about that situation. The manufacturer will absorb a considerable amount of that and doesn't make a change until he has to.

Mr. Pisciotta. Does the manufacturer absorb it in pea beans?

Mr. Toulme. Apparently that manufacturer felt he couldn't. 
Mr. LevirT. Isn't it a fact, that a 14-ounce package is put up for a certain class of trade?

Mr. PisciotTa. That isn't true of this particular one, because it was cut from 16 to 14 ounces and every one of these boxes is now sold at 14 ounces.

Mr. R. A. SNyder. Mr. Chairman, I have sat hele for several hours and listened to this, and I might say I know something about the wholesale grocery trade because I was in it. I don't know why we cannot get through with this. It is a known fact that a manufacturer packs a 14- or 16-ounce package for certain classes of his trade; there is no question about that. The reason for the difference in the size of the package is in order to meet competition with this chain-store trade. For instance, for years a brand of raisins was packed in 11and 15-ounce sizes.

Why cannot the manufacturers and the sellers get together on a standardization of packages which would save the manufacturer the additional cost of cartons and cans; the manufacturer would make money, the retailer would make money, and every sealer throughout the country would be satisfied.

The Acting Chairman. I think it is the purpose of the discussion to make feasible that accomplishment.

Mr. Piscio'tTa. The reason I have asked these questions is to bring the arguments out. I know the answers. I believe you want to know how to act on the recommendation of the Committee. I know how I am going to vote, but I believe you want to find out from these gentlemen.

Mr. Toulme, is there any reason why peas should not be packed in 2-, 4-, 8-, and 16-ounce packages? Is there a justification for a 7-ounce package of peas?

Mr. Toulme. Well, suppose a man went into business several years ago and decided he was going to popularize a 7 -ounce package of peas, and he did it. After that man has spent several millions of dollars for good will, why say it is a crime to sell a 7-ounce package? It is sold at 7 ounces, and paid for at 7 ounces. How is the consumer hurt?

Mr. Piscrotta. Did you ever hear of a customer coming in and asking for 7 ounces of peas?

Mi. Toulme. No.

Mr. Pisciotta. How about a half pound?

Mr. Toulme. Yes.

Mr. PIsciotra. When he asked for a half pound, this package was given to him?

Mr. Toulme. The conversation is this, "I haven't got a half pound of peas, but I have 7 ounces and I am going to charge you for 7 ounces."

Mr. Pisciomta. Are you sure that is what happens?

Mr. Toulme. Yes, I am sure.

Mr. R. A. SNyDER. Isn't it a fact that the charge is the same?

Mr. Toulme. No.

Mr. R. A. SNYDER. I happened to be a sales representative of a tea company and for a number of years we packed tea, in quarter- and half-pound sizes, and then in the 7-ounce size. We did that for one reason-in order that our price would be cheaper and meet competition. I want to go on record here that I am for a uniform package. 
There is no reason why in the State of Pennsylvania we should have one package size and other sizes in New Jersey, in New York, and in Massachusetts. I think the manufacturers could save a lot of money if they got right down to brass tacks and made the same package.

Mr. Toulme. Well, I think everybody in this room and in the food business wants to achieve your objective. We are willing to help.

Let me ask you a question: There was a wide-open question, and no answer, in relation to the voluntary program, to the effect that somebody could stay out and wreck us. I am wondering if this Association of yours cannot come into the picture when a producer or processor of that type stays out, and ask him why he is staying out.

Mr. Pisciotta. The Conference and some individual weights and measures sealers throughout the country perhaps, by prosecution or otherwise, may be in a position to compel certain outlaws to go along on a voluntary basis. But isn't it true that all sealers throughout the country may not be in a position to do that?

Mr. Tovlme. Well, I don't know about that. I merely propose the question to you. With a firm such as this, what persuasion other than this can you use?

Mr. Pisciotra. A law to compel them to do it.

Mr. Tounme. I should think if you can get the trade to agree, you would not have any trouble.

Mr. Pisciotra. We have tried for 2 years and succeeded with many people but we have not been entirely successful.

Mr. Toulme. Then there must be some very good reason I am not familiar with.

Mr. Pisciotta. This was one of the reasons we discovered. 'These two packages (indicating a half-pound and a 7-ounce package of tea) are on the shelf alongside each other. There is a tag above this shelf, 40 cents; there is a tag above this shelf, 35 cents. The housewife walks in and the 35 -cent price appeals to her; she thinks she is getting it 5 cents cheaper. She doesn't realize she would have paid the same price if she had bought the other; both were 5 cents an ounce. She never figures that out.

Mr. Toulme. I don't know whether she does or not. I find these women are pretty cagey. She may know she gets 7 ounces in one and 8 ounces in the other.

Mr. Pisciotta. Without reference to these women here, I have found women to be the most duped buyers. I have asked hundreds of women who have bought this for years and years, and 75 percent of them were under the impression that they were buying a half pound. Will you agree with me, that is the reason for the difference in weight?

Mr. Tounme. I am not going to do that. But we do believe in keeping up that campaign of getting consumers to read the labels. The truth is there, and there is no fraud. It is a lot easier for the consumers of this country to take the time to read and understand the labels, than to go down this other route, which involves a lot of legislation and the freezing of conditions, when we don't know what we might want 6 months later.

The Acting Chairman. Mr. Toulme, the Conference thanks you for this discussion.

At this time I will invite Vice President Tucker, of the Sunshine State, to preside.

(At this point C. E. Tucker, Vice President of the Conference, assumed the chair.) 
PAPER PRESENTED BY F. F.FITZGERALD, DIRECTOR OF RESEARCH, AMERICAN CAN CO., REPRESENTING THE CAN MANUFACTURERS INSTITUTE, INC.

No one will question the desirability of the standardization of canned-food containers.

From the weights and measures standpoint, the object of standardization is the protection of the consuming public from deception that may arise from the use for the same product of cans varying only slightly in capacity.

From the canners', brokers', and retailers' standpoint, the object of standardization is to limit the sizes of cans used for each product to those sizes which have been found to satisfy the trade demands, and thus prevent unfair use by competitors of deceptive-appearing containers.

The can manufacturer is wholly in sympathy with this program, provided the standardization is economically sound.

The can manufacturer, canner, merchandiser, and the consuming public agree as to the desirability of standardization, but the can manufacturer insists that such steps as are taken in this respect should not so hamstring the industry as to prevent continuance of the scientific development that has characterized the industry during the past 20 years. It is from this scientific point of view that I wish to approach the question of standardization.

The tin can was never designed as a measure and never can be one. A short history of the development of the can, or canister, will make this clear. After the invention of the tin can by Durand, cannerswho then had a small output-made their own containers by hand, usually in the winter months. The sheets of imported tin plate were cut laboriously with tin scissors into body lengths and rolled around an iron body form and soldered. Circles were cut from sheets for ends-the top end with a large hole in it. The three pieces were then soldered together by hand. After the can was filled with the fruit, fish, or vegetables and heated to expel air, the caphole was closed and the venthole soldered.

Gradually these primitive methods were improved. Dies were used to punch out ends-thus the first attempt at standardization. During this period the canner provided the tin plate, cut out the can parts, furnished the coal and the cappers, and piled the finished cans. The laborer making the cans was paid a fixed sum per thousand cans, but his contract provided that he pay not only for the value or cost of any defective container, but also for the value or loss of the can contents of any defective container.

This type of container remained in use for years. The capping and tipping of these containers in the canning factories gradually became a highly specialized operation, and quite generally was let by contract to boss cappers, who hired their own crews and worked for a fixed sum per thousand cans, with the definite agreement that they would pay, not only for all cans showing defective cap and vent closure but also for the contents of such cans. This is one of the first instances of consequential damage contracts.

The automatic body maker was then developed, and as cans could be fabricated by these machines at much less cost than by hand, the canner naturally bought his cans from a can maker who could afford to install such equipment. As the canner formerly held his em- 
ployees responsible for defective containers he now asked and received a guarantee from the container manufacturer against delivery of defective containers. This guarantee was initially against spoilage above five cans per thousand, later three cans per thousand, and now two cans per thousand. Under the terms of these contracts, food containers are guaranteed against spoilage or other loss due to defects of the container chargeable to the can manufacturer, above two cans per thousand. This covers not only the cost of the defective container but also consequential losses due to spoilage of contents.

These contracts were the stimuli for the scientific development of the canning industry. Fundamental investigations were necessary to establish the individual responsibility of the can manufacturer, the canner, and the distributor.

Complete knowledge of the procedures and methods used by all concerned is necessary. The character of the canner's raw product, the methods of planting fertilizing, spraying, harvesting, washing, grading, blanching, filling, closing, exhausting, cooling, and warehousing had to be studied. This also entailed a study of the design of equipment, materials used in equipment, and methods of shipment and storage of finished product.

Only two decades ago a can was a can. Only two kinds of tin plate were known-open hearth and bessemer. These could be purchased with so-called coke, canner's special, or charcoal weights of coating.

Today, with the development of new processes of manufacture such as the cold methods of reduction, the canner is furnished with containers especially designed for the particular product he is canning. The chemical specifications of the base plate, the methods of manu. facturing the plate, i. e., hot mill or cold reduction, the temper of the plate, the weight or gage of the plate used in the bodies or ends, the profile of the ends, the design of the body, the weight of tin coating, and the character of enamel-if enamel cans are used-are specified. These specifications are fixed and are absolutely necessary if the can is to serve its proper function, which is far beyond that of an ordinary measure. Let me repeat, the canner is furnished with containers made according to specifications and designs adapted to each particular product he is canning.

The container is a miniature steel retort or boiler which acts efficiently in the sterilization of the canned food, and which later can be used as a container for the storage, distribution, and sale of the sterilized product if properly made of suitable material. Canners would not accept today the containers which their fathers used. Development of new types of plate has doubled the shelf life of many canned foods, but at the same time has forced can manufacturers to change their methods of manufacture and the design of can bodies and ends so as to counterbalance the physical weakness of these new types of plate. Beads on the bodies of cans and the apparently ornamental ends are not accidental but are the results of fundamental engineering study.

This short historical survey is given to show that for a century and a quarter the tin canister has been regarded as a container and that the primary object of the scientific staffs of the can manufacturers and canners has been directed to the development of new plate, new processes, etc., which will enable the industry to make a product of increasing merit and one that will retain its high quality during the period of storage and distribution. 
The contents of the container are not necessarily measured by the external dimensions of the cans. Differences in types of cans, side seam bow, profile of ends, methods of fill, temperatures of fill, methods of exhaust, and methods of closure prevent the can from ever being other than a container.

Numerous examples may be cited. With adoption of cold-rolled, low-metalloid plate, paneled bodies were encountered with the larger size of cans for pumpkin. Pumpkin cans must be filled at high temperature on account of their slow heat penetration. This difficulty was partially solved by the use of "domed" or convex ends, which permit the use of a normal fill but produce a lessened head space in the can, thus reducing the final vacuum and lessening the paneling. With citrus products, the use of nonspilling closing machines and gasflow closure demands a can shorter than the former can, although both contain the same volume of contents. With vacuum filling machines for pork and beans the can may be shortened in height with the finished can containing the same cut-out weight.

Products are packed in cans which are scored on the body near the ends and opened with a key. If these products are liquid or semiliquid, the cover is depressed so that the food will not leak out when the can is opened. The heights of some sizes of salmon cans differ according to whether the cans are hand-filled or machine-filled. The machinefilled cans are two-sixteenths of an inch higher than the hand-filled in order to guarantee the same cut-out weight. Tomato juice packers must vary the heights of containers to compensate for temperatures of filling. Packers who fill at $160^{\circ} \mathrm{F}$ can use a shorter can than those who fill at $190^{\circ}$ to $200^{\circ} \mathrm{F}$, because of less contraction on cooling. The trade demands a uniform quantity of product in this case and is not interested whether the can is one-sixteenth of an inch taller or not.

The Federal Government contracted for roast beef in cans containing 24 ounces. Those packers who used thermal exhaust could use a can three-sixteenths of an inch shorter than those who used mechanical vacuum. The Government was not interested in the dimensions of the container but in the quantity of food in the container. Numerous other examples could be given.

As stated before, efforts to increase the service life of containers demand changes in chemical composition of the tin plate. These changes in chemical composition cause differences in physical characteristics of the tin plate, and these changes in physical characteristics cause subsequent changes in body design and profile, and in methods of canning and merchandising.

The can manufacturers, as well as all other factors in the food industry, are vitally interested in can standardization, with the immediate purpose of preventing consumer deception, but they ask that such standardization be made without freezing the scientific development of the can manufacturer and canning industry.

I believe the standardization committee has presented an excellent program. As a matter of fact, there could be, in my opinion, only one criticism offered, and I believe this criticism is secondary. Canada also considered, for instance, the idea of stepping up the sizes of cans by 4-ounce intervals but soon saw the impracticability of such an 
idea and now recognizes 66 sizes of containers. These 66 sizes are used for many less products than are now canned in the United States.

Arbitrary minimum nondeceptive volumes of fill corresponding to the figures established by the BAE and enforced under the Federal food law, or average declared fills, must be established for each product and it is immaterial in what units such volumes are expressed. This is necessitated by differences in specific gravity of products, methods and temperatures of filling, methods of closure, necessary differences in end profile design, etc.

It would be extremely desirable to have at least a uniform method with Canada, England, Australia, New Zealand, South Africa, etc., but the British nation uses a different gallon and fluid ounce than ourselves. We are in the same position with France and continental Europe, who use the metric system. It is extremely unfortunate that our weights and measures are not on a decimal basis like our monetary system, but it would be foolish for us to try either to adopt a new system of weights and measures or to change the quantities which have been found desirable in the trade. We probably must base our volumes on a cubic inch or the fluid ounce, but, as previously stated, the choice of units is a secondary matter, as the prevention of consumer deception is all that is necessary from the weights and measures standpoint.

In conclusion, let me say, first, the can manufacturer will make all sizes of cans demanded by his customers; second, the can manufacturer will be forced to limit his responsibility for the service life of containers to the extent that the can specifications do not accord with sound engineering and technological processes; third, the can manufacturer maintains that the tin can is an inherent tool in the production of canned foods and that its subsequent use as a container is a fortunate coincidence that has made the industry possible-however, this use as a container is so involved with physical and chemical considerations that the external dimensions of the can should not, and cannot, be taken as a precise measure of the contents of the can; fourth, canned-food containers may readily be standardized by the simple method proposed by the industry committee, which establishes volume fill as a basis.

This proposal suggests, first, that standardization be established by products; second, that there be established for each individual product certain volumes which may be packed, making these so different in quantity that the containers will not be confusing to the purchasing public; third, that in following the above program no mistake be made such as trying to change our whole system of weights and measures, but that we select those commercial containers which comply with the different requirements and whose use can be established with the least cost to all parties concerned. International standards may later be developed, but let us not now overemphasize the gill, pint, quart, gallon, and pound, as even these units are at times grossly misunderstood. We have the dry quart and the liquid quart; the Imperial gallon, the United States gallon; the troy ounce, the Imperial ounce, the avordupois ounce; and other units. It is not our business to fix the definite units of measure but only to see that there is no deception to the consumer. 


\section{DISCUSSION OF ABOVE PAPER}

Mr. Pisciotra. Dr. Fitzgerald, our recommendation No. 5 pro. vides:

Containers of different standards to be so constructed that the different sizes are easily discernible, this to be accomplished by fixing the diameter or the base measurements of the container and letting the industry change the height of the respective containers to fit the particular commodity.

Now, you could put out a 16-ounce container for different commodities, according to the nature of the commodities, and the temperature at which it has to be sealed, by varying the height of that container.

Dr. Firzanald. Theoretically, it is possible. The objection to it is that you would run the number of the containers into the thousands, so that, instead of having 55 , we would have 2,500 .

May I give you another example? A question was asked about marking of 16 and 15\%/ ounces. I think Mr. Campbell well explains that where the indicated weight on the can varies. You start the season early, and the first corn coming in is not mature. We like to fill corn at $190^{\circ} \mathrm{F}$, to get air out of the corn. But if you heat this green corn to $190^{\circ}$, it would be absolutely impossible to get your weight. You have to drop it to $170^{\circ}$, and then you are in danger of getting under the minimum weight. Maybe a week later, a new field will come in and you will have no trouble getting the weight in.

Mr. Pisciotra. Then if you purchase that same size can in another part of the season, you wouldn't get the same weight?

Dr. Fitzgerald. The chances are that you always get the declared weight. I would say the weight would tend towards the minimum at times, and at times towards the maximum. They always mark the weight at the minimum.

Mr. Piscrotta. We would get the same markings on the label. Whether it was $14 \frac{1}{2}$ or 16 ounces, it wouldn't make any difference?

Dr. Fitzgerald. Yes, you would always get the marked weight.

Mr. Piscrotra. Then it wouldn't make any difference about this difference in the corn, you would still have the same container?

Dr. FitzGerald. Not in all cases. If you are canning tomato juice. in the 12 -ounce size at $160^{\circ} \mathrm{F}$ and at $190^{\circ} \mathrm{F}$ there would have to be different sizes for the different temperatures.

Mr. Pisciotta. Do you recall these two 15-ounce cans [indicating cans of coffee] and the reason given to us for not being able to bring this up to 16 ounces?

Dr. FitzGerald. I image the reason for not bringing it up to 16 . ounces is that the packer doesn't want 16 ounces in there.

Mr. Piscrotra. Do you remember, Dr. Fitzgerald, that you said that if this was raised a fraction of an inch, there might be a danger of collapsing the can?

Dr. FitzGerald. I remember we didn't say a fraction of an inch. You can perhaps get more coffee in that can. The lighter the roast the heavier the coffee, and the more you get in.

Mr. Pisciotta. You remember you told about the impossibility of changing this to 16 ounces?

Dr. Fitzgerald. As I remember, you were talking about changingit to the diameter of 404 . We can increase the height of that can within certain limitations, but the amount within which you can increase the height depends upon the diameter of that can. 
Mr. Pisciotra. The weight now has been increased to 16 ounces and the can is a little higher. This is an example of one commodity, different brands, with four different sized cans. I am trying to illustrate it was possible, although we were told it was impossible, to change the can to 16 ounces.

Mr. Ackerman. Dr. Fitzgerald, you have been very kind in answering all of our questions, and I would just like to ask if I were a manufacturer of a food product and ordered some gallon cans from your company, would you at my request make a deeply recessed lid to fit those cans so that they would be short approximately 812 cubic inches?

Dr. Fitzgerald. No, I do not think we would. We have had that put up to us and we declined.

Mr. Waldman. Mr. Chairman, it isn't my purpose to curtail or limit discussion on this thing, but I would like to suggest that it seems to me perfectly obvious that all of the answers given to Mr. Pisciotta's inquiries have been identical. I am thoroughly convinced, and I believe most of the members of this Conference are convinced, that there can be a method of standardizing packages. I see no need for asking each successive speaker the same questions and getting the same answers.

I believe that this Conference is deeply indebted to Mr. Pisciotta and his Committee for their study and effort and the time that they have put forth on this all-important subject. But I would like to see some of the discussion limited; this subject could be discussed from now to the end of the Conference, and we wouldn't know any more then than now.

Mr. J. G. Rogers. Mr. Chairman, I feel the same way as Mr. Waldman. When we have developed all of the technical features, I would like to be heard. I have been trying to hold myself back until that time.

The Acting Chairman. If the Conference wants to rote on this question now we might bring this particular phase to a close.

Mr. A. Edward SNyder. Mr. Chairman, these men are, as I see it, representative of the various industries, and when we hear the final two speakers we should have more or less of a complete survey.

Mr. Piscrotta. May I say, Mr. Chairman, that I think we are finished and can go along without further questions.

\section{PAPER PRESENTED BY J. S. ALGEO, HAZEL-ATLAS GLASS CO., REP. RESENTING THE GLASS CONTAINER ASSOCIATION OF AMERICA}

I speak as a representative of the glass-container industry, manufacturers of bottles and jars for foods. The glass-container industry is engaged in a broad program of redesigning and simplifying its packages, and this program ties in with the general idea of this Conference and also with the deceptive-package feature of the Food, Drug, and Cosmetic Act. The primary purpose of this program of ours is to reduce our costs of production so that we can sell our containers at lower prices and thus obtain greater distribution. It is obvious that with fewer styles and sizes to make, we can produce them at a lower cost; so if by simplifying and standardizing our packageswhich is the objective you have in view-we also benefit ourselves, then we are killing two birds with one stone. We are helping ourselves and also working toward your objectives. 
Glass-container designs up until a few years ago and still, to a very great extent, were relics of the old days when bottles and jars were made by the so-called hand-blown method, before the days of mass production by automatic machines. Because costs were lower and because there was not as much difference as now between the cost of producing items of various styles, but of the same sizes, there was a pronounced tendency to make containers so that they would look as large as possible with relation to the actual capacity. This tendency largely accounts for the extra-tall bottles which you see today and for tall bottles with depressed panels in their sides and of other shapes which look large in comparison with a simple round shape which holds the same. Likewise, because mold costs with relation to the total costs were much lower then than is true now, there was a tendency to build molds for smaller quantities than would now be considered economical and for freakish shapes which would now be considered impractical. This fact accounts in a large measure for the multitude of bottle and jar designs that are now in use. There is no question but that the glass-container industry is making more shapes and sizes than are needed, and it is this condition which we are endeavoring to correct. It is a fact that a plain round, relatively squat, glass container is the easiest and cheapest to produce and that the farther away we get from such a shape, the greater the cost of producing: Thus it happens that the least deceptive glass container is also the lowest in cost, and thus it happens that it is to our interest to simplify and standardize our container's.

This program of redesigning and simplifying design has not taken the line of bringing about complete standardization-by which I mean we have not attempted to design a jar to hold, say, 1 pound of preserves so that all 1-pound preserve jars made by all manufacturers would be exactly the same. It has taken the line of developing general standards of design within which general standards any glass manufacturer may vary his design to suit his own or his customer's preference or requirements. In actual practice the result is that jars or bottles intended for the same product are pretty much alike, regardless of the manufacturer, because if the general standard is complied with, there can't be a great difference in the bottles or jars produced by different manufacturers. At the same time, there is room left for a variety in style, which we find is still demanded and which we believe will continue to be demanded, because one of the chief merits of a glass container as a package for food is its eye appeal. This eye appeal helps to sell food in glass; and so in order to make best use of this eye appeal we believe that variety in design will always be demanded, both by the packer and by the consumer. In actual practice this program also results in our being called upon to make fewer items than heretofore on account of the elimination of many odd and freakish designs due to the fact that the packer has a wide choice of designs in stock packages which suits the packer's requirements much better than his odd or private mold designs. In turn this concentrates our production on fewer and more desirable items, all of which makes for lower costs.

The technique of making glass containers has improved to a very great extent during the past 15 or 20 years. We can make them faster than we could then, and, equally important, we can make them at lighter weights and stronger. Through this redesign and simplification program we are trying to take full advantage of this develop- 
ment in technique, and in doing so we are not merely designing containers that are more practicable from our standpoint, but we are also designing them to be more practicable from the standpoint of the packer and of the distributor and of the consumer. We are designing containers which are most practicable to manufacture with our present-day equipment; and since they are most practicable, they are also most economical; and, again, since they are most practicable, it results in greater uniformity in design as between containers made by different manufacturers; and, finally, since they are most practicable from a manufacturing standpoint and most economical and more uniform, this program of the glass industry ties right in with your program and with the Food, Drug, and Cosmetic Act.

What I have just said refers to simplification or standardization of design rather than to standardization of sizes. As we see it, there is not much the glass-container industry can do toward standardizing sizes. That will have to come from the packer who uses our containers. We would, however, welcome a greater standardization of sizes than now exists, because such a standardization would round out and complete our simplification program. As a matter of fact, we are endeavoring to the extent of our ability to limit the number of sizes. In this program of ours we are setting up specifications for only the sizes that are most popular and doing our best to sell only those sizes. In addition to that, we plan to cooperate with food industries using our containers in an effort to further our program of simplification and standardization. In my opinion, it would not be practical to standardize to the point where we would have one line of jars for packing all sorts of semisolid products and a line of bottles to pack all liquids. Each kind of product has its own characteristics and oftentimes requires a special type of container. Jams, preserves, mayonnaise, and mustard require jars with fairly wide openings. Pickles, if "placed" in the jars, as opposed to being "thrown" in, require jars of certain heights and diameters and with a certain type of shoulder in order to hold a certain number of pickles and to prevent floating. Olives, when "placed," require a certain type of jar for the same reason. Even bottles to hold liquids could not be of the same sizes for all products, because some liquids require greater head space to take care of the greater expansion of one liquid than another. Products sold by weight sometimes vary in specific gravity, hence they require jars of different capacities to hold the same weight of contents.

The best that could be done would be to adopt standard sizes for each type of product going into a container, and while there are many obstacles against bringing about a complete standardization in that respect, and while I doubt whether it would be in the best interest of the public to do so, nevertheless there is a very great amount of standardization of sizes now, and the tendency seems to be increasing. Milk bottles, mostly through State laws, are standardized as to size-quarts, pints, half pints, and quarter pints, and, in some States, one-third quarts and 10 ounces - the last two sizes mostly for the restaurant trade. Milk bottles, as to styles, have been standardized through the cooperation of glass manufacturers and milk companies. It is certainly fitting and proper that containers for such a vital necessity as mill be standardized so that the consumer cannot possibly be deceived and so that the containers can be produced and 
sold at the lowest possible level. Household fruit jars, for many years, have been standardized in half-pint, pint, quart, and halfgallon sizes-not through any particular cooperative effort but by common consent. This is an advantage to all concerned. In recent years mayonnaise containers; honey containers; and preserve, jelly, and apple-butter containers have been standardized as to sizes, but not as to styles, through the cooperation of these various industries with the National Bureau of Standards. These standards have been observed fairly well but not absolutely-and I don't see the necessity, nor even the wisdom, of bringing about an absolute standardization of containers for products which are not necessities, as in the case with milk.

From a selfish standpoint, the glass manufacturer would welcome a greater degree of standardization of sizes, but we feel we are almost powerless to bring it about, because, after all, we are obliged to furnish what our customer's want. If one manufacturer refuses to make a certain size, his competitor will make it. My observation is that there are many obstacles to a rigid standardization of sizes. One of the most important is the fact that foods, to a great extent, are packed to retail at certain prices-for instance, 10 cents or 25 cents. When the price of raw materials goes up in cost-for example, peanuts for peanut butter-then the amount to retail in a jar for 10 cents goes down and a smaller jar is needed. The reverse is true when the price of peanuts goes down. The American housewife seems to want to pay only certain popular prices. She wants to buy a quarter's worth of peanut butter or jam. If a grocer asks 27 cents, she oftentimes does not buy. I am not qualified to speak on such a subject, however, as it is the problem of the packer to whom we sell our glass. I am confident, however, that this popular-price complex is a serious obstacle to enforcing a rigid standardization of sizes, and I don't believe any enforcement should be attempted except such as can be obtained by voluntary cooperation among members of the same industry, and the amount of this cooperation and the success of the venture will depend upon many factors, such as the state of business, competition, cost of production, location of consuming area with respect to the manufacturer, and so on. To attempt an enforcement of an arbitrary standard of size when that size does not synchronize with production costs and with the purchasing power or buying habits of the housewife, is running a serious risk of curtailing business. The housewife is the purchasing agent for the household, and the manufacturer must produce what she wants or he does no business. We believe that a certain flexibility must exist in order to keep in tune with changing conditions, for, after all, it is more important to get food products to the consumer at the lowest cost and in greatest volume than it is to maintain a rigid standard for sizes. The attitude, therefore, of the glass manufacturer is that we would welcome a further standardization of size from our own selfish viewpoint but that we cannot enforce such standards, and it is doubtful whether an arbitary enforcement would be in the public interest.

The glass manufacturer's chief function at this time, in my opinion, is primarily to improve the design of the container so that it will be more practicable to all concerned, and, secondarily, to reduce and standardize the sizes-necessarily following the demands and requirements of his customers and the food manufacturers in that respect. 
We are endeavoring to perform these functions, and in so doing we are furthering the objectives of this Conference by the following means:

We are designing and producing containers which are more practicable from our standpoint. Being more practicable from a manufacturing standpoint, they are produced at a lower cost, and this saving is passed along to our customers and to the public.

We are designing and producing complete families of containers of one general style so that a packer, if he has to change the size of his container because of increasing or decreasing costs, or for other reasons, can do so quickly and without having to have special molds built. This results in greater flexibility, both for the glass manufacturer and the packer, and necessitates a fewer number of molds on the part of the manufacturer in serving his customers.

We are producing containers which are more practicable from the packer's standpoint-more uniform and less freakish in designmuch lighter in weight, and yet stronger than old-type containers. The packer thus obtains greater speeds on his filling lines and less. breakage, and because of lighter weights he makes a very considerable saving in transportation costs, which eventually benefits the consumer.

We are producing containers which are more practicable from the consumer's standpoint-containers which fit better on pantry shelves and in refrigerators, and even more important, containers from which the contents can be removed without spoiling his or her chances of reaching heaven.

Finally, we are producing containers which, because they are simple in design, cannot be considered as being deceptive.

It is not to be inferred from my remarks that this program of simplification has been completed-it is well under way and great progress has been made, but the greater part has to be done. When completed it will result in our having containers which are more practicable from the point of view of all interested parties, fewer items and lower-cost items. It has been my purpose to tell you of the program which the glass container industry has outlined, and to show you that it synchronizes with the work in which you are engaged. We are in favor of simplification and are working to that end and are willing: to cooperate toward further simplification and standardization within the limits of the peculiarities of our own product and of the requirements of our customers.

The Acting Chairman. Thank you very much, Mr. Algeo.

\section{PAPER PRESENTED BY CHARLES R. COSBY, EXECUTIVE SECRE- TARY, LABEL MANUFACTURERS NATIONAL ASSOCIATION}

Labeling is an intermediate step in the process by which goods in containers are distributed to consumers whose in terests deserve certain safeguards as a matter of public policy. It is a reasonable expectation that honesty and fair dealing shall prevail among those who offer a public service while enjoying the privileges and profits of our system of private property and free enterprise. Granted that consumers are entitled to buy what they want from sellers who are offering their goods in the market places, the problem is to insure a meeting of the minds without coercion or deception. Naturally, this calls for a common understanding of terms and definitions and is, in effect, what is meant by the expression "Standardization of Packages." The problem of creating that common understanding of terms and definitions is uppermost 
in the minds of officials charged with the interpretation and enforcement of sound public policy. Government has the right to declare that certain terms or definitions shall be used only with a certain defined meaning. Private industry has the capacity to familiarize consumers with the physical characteristics of the goods so described. The inducements which normally influence private industry to assume that task will be mentioned later in this study of the subject.

The fact that labeling is a middle step along the route from production to consumption makes it possible for label manufacturers to look in both directions, as it were, in considering the questions that arise. In the same way that convenient packaging has proved itself an important element in the vending of commodities, informative labeling has become an indispensable link in the point-of-sale identification of goods. The problems of standardization have a double effect upon the business of preparing suitable labels. First, there are problems pertaining to packages and their contents; and second, there are problems pertaining to the preparation and use of labels. If the label manufacturers shall be able to contribute some helpful thoughts to this interesting subject, it will be due to their practical experience with a wide variety of containers affording them an excellent opportunity to observe the causes and conditions that tend to create diverse rather than common characteristics in containers and labels. These tendencies to generate irregularities are the forces with which one contends when searching for acceptable and practicable standards.

Looking backward toward the beginning of the producer-to-consumer route, the label manufacturer observes that in a system of free enterprise the vending of merchandise at retail is an activity offering a wide range of choice in respect to the manner of its accomplishment. Good judgment in appraising and satisfying the wants of the buying public is rewarded by volume sales, mass production, and low costs. The choice of an acceptable unit of quantity is made after a careful study of the consumer's needs and preferences. The choice of a suitable container depends not only on the quantity to be sold but also the physical aspects of the product. Nothing is neglected which may be used as a means to influence the consumer's preference among the many uses for her money. The consumer's freedom of choice is therefore the proving ground on which are developed the effective want-satisfactions, the efficient distributing system and the highest rewards for the enterpriser. The success of this system has been too well proven to need any special pleading at this time.

Looking forward to the consumer and her day of marketing, one is impressed with the tremendous responsibility borne by the label when it comes to the counterside decisions made by her in choosing from the vast assortments of packaged goods. Ample evidence of the strategic position of the label at this point is the huge sum spent for naturalcolor reproductions and the artistic merit of labels intended to represent the high quality of the food contents. Does the consumer know how to evaluate the claims of rival products? Does the label tell facts which she wants to know? Can she rely on what she sees? It is not the fault of the consumer when she is unable to find consistency in the claims of quality and quantity. Lacking authentic information, she is often without the means of making comparisons and -evaluations. A packaged product does not always offer favorable opportunities to examine and appraise the goods. Substitutes for 
those opportunities to see and evaluate do not appeal to the same faculties of mind. Here is a demonstration that the consumers' choice is dependent upon a common understanding of the term or definition of identity by which a product is called. The overzealous seller is apt to indulge in exaggeration. The statement of weight may be as unconvincing as a mathematical symbol. The quantity is sometimes "generously" represented by means of oversized containers. In a practical sense, quantity and quality either balance or unbalance each other. For example, 8 ounces of canned soup may be equal to 16 ounces of the same quality of soup diluted with water. The proportion of inert ingredients affects both quality and quantity. This partly explains the need for a definite standard of quality. There are many analogies between foods and drugs, but there should be more. In the field of medicine, a drug is not standard unless it is defined in the official compendium.

One should not assume that the education of the consumer in respect to standards is an unrequited labor on the part of the sellers of packaged goods. On the contrary, it offers handsome rewards to those who are ambitious to serve the public for profit. The economies of mass production are made possible by the fact that manufacturing processes may be standardized to the point that automatic devices can be set up for long runs of identical operations. The frequency of any operation determines whether machines and tools shall be set for automatic or hand control. The materials either cut economically or they cut wastefully. The materials from which containers are made, such as wood veneers, tin plate, paper, paperboard, fiberboard, glass, etc., are all subject to their own manufacturing conditions which determine the most adaptable sizes and dimensions.

Under present conditions the label manufacturers can have no preconceived notions in regard to the shapes or sizes of containers in which goods are packed. They are asked to make labels to fit certain containers and they make them that way, as economically as conditions will permit. Label manufacturing is a made-to-measure proposition. There is practically no such thing as a stock label. No two product labels are alike in all respects. Too many of them are unlike in every respect. There are said to be as many as 150 different sizes of labels for cans for fruits and vegetables. Obviously, labels for all these sizes cannot be cut economically from any one size of paper sheet, which means that label manuiacturers must be prepared with many sizes of paper, and the paper mill must produce such sizes from the paper machine, whatever may be its width. And it means that printing presses of various sizes must be available if the work is to be done economically.

If a canner wishes to change the capacity of a can, he may change either the height or the diameter, or both. If all cans were made the same height or the same diameter, labels could be made uniform in at least one dimension and it would be possible to set the paper-cutting machines so that their operations could be repeated with sufficient frequency to effect economies in production. All that has been said about cutting label paper applies in principle to the manufacture of cans from tin plate. Both are cut from stock of certain limited sizes.

Prospects of economies in label production are dependent upon long runs of uniform sizes of labels, and of course that depends upon greater uniformity in the sizes of containers which the labels must fit. 
If the sheet cannot be completely filled with labels of the same size, economies cannot be effected. If the sheet is only partially filled with a variety of labels of different sizes, a waste of paper is inevitable-not raw paper but paper bearing a labor cost of many handlings. The greatest economic loss, however, is due to the substitution of timeconsuming hand adjustments in platemaking, and in cutting finished labels from the sheet, a process that has some of the elements of a jigsaw puzzle.

Labels for boxes, bottles, crates, cartons and in fact all classes of labels suffer from such variations in the sizes of containers.

The machines that affix the labels to the containers are also adversely affected by a variety of sizes. Each change requires a stoppage of the machine and the adjustment of the mechanism that holds the labels in position. Of course this retards the production and increases the cost.

Packing cases cost less when made in standard sizes. Special can sizes make it necessary to use oversized or odd-sized cases which are not efficient in proportion to their shipping weight.

It would be difficult and perhaps tedious to enumerate all the collateral effects set in motion by even slight departures from customary or natural forms. There is ample evidence that too many variations in quantity and quality are the result of misdirected zeal. Most careful observers now agree that there should be an authoritative standard of identity of every product sold in a container. The methods for attaining that objective are not entirely clear. Experience in that field is too recent to admit of dogmatic opinions. A division of responsibility between government and private industry seems to be the course best calculated to serve profitably both private industry and the consumer.

Probably the most important contribution to consumer familiarity with contents and can sizes was made by the late Dr. Bigelow, who established in true scientific fashion the proper weight of contents for each size of cans of normal quality fruits and vegetables. This was a self-imposed task under the direction of the trade association of that industry, the National Canners Association, and it is a splendid example of the cooperation which organized industry is able to offer in the field of standardization.

The process of educating the consumer probably should be based on uniformity of method in declaring the required label information. In matters of education one can borrow profitably from the field of applied psychology. If four facts regarding the product must be stated, there. should be a rather definite pattern for presenting those four facts, free from obscuring data, so that the absence of any essential declaration will be noticed. Any departure from a legally defined standard of identity should be indicated in a specially allocated label space and. in prescribed terms. The relative prominence of essential data should be definitely fixed. When the consumer can see that there is. consistency and uniformity in presenting the terms and definitions by which the merits of competing products may be judged, she will become a discriminating buyer and the merchants seeking her favor will not risk offending her by inadequate information. When the consumer becomes better accustomed to the standardization of packaged goods, the packer will have less excuse for odd sizes and 
more regard for the economies and other rewards of the policy of standardization.

The Acting Chairman. Thank you, very much, Mr. Cosby.

Mr. Boyle. Mr. Chairman, I would like to ask the last speaker if there is any attempt to regulate the labeling of quantity. Frequently you will see a statement of "average weight, 8 ounces," or "not less than 8 ounces," or "not less than 8 ounces when packed." I have here a label from bread, which reads: "net weight 15 ounces, or less." What does that label mean?

Mr. CosBy. I will not undertake to answer for the producer of the product. The label manufacturer takes his orders from his customers and does not inquire as to the honesty of the weight declaration, or matters of that sort. That question probably should be directed to the producer of the product rather than to the label manufacturer.

\section{GENERAL DISCUSSION OF REPORT OF CONFERENCE COMMITTEE}

Mr. Busser. Mr. Chairman, I would like to make a motion that the report of the Committee be adopted and approved and that the present Committee be continued with such changes in the personnel thereof as the President of the Conference deems necessary, the Committee to confer with the different branches of the industry for the purpose of working out and seeking the introduction of necessary legislation pertaining to standardization of package commodities, as outlined in the Committee report.

Mr. Levitr. Mr. Chairman, Mr. Pisciotta and his Committee spent a great deal of time on this matter and are to be congratulated on the wonderful job they have done. I realize today there have been some matters put forward that will probably need some further consideration and discussion. However, I think this is one of the most progressive steps that has been made by the Conference, and while I have not gone into it personally, I am satisfied to take their views in this matter. I want to second the motion as put by Mr. Bussey, of Texas, for the adoption of the report and the continuation of the Committee, and for their meeting with these various people, so that the differences that have arisen can be settled and adjusted.

Mr. J. G. Rogers. Gentlemen, I have sat here this afternoon and listened to all the ramifications of this subject. I think in principle we are all in agreement with what the Committee is trying to do. But the subject is replete with technicalities and there is danger in moving too fast. I am thoroughly in accord with the thought that there have been abuses in the package packing industry. However, the packing industry has its problems, too, undoubtedly, and we have to approach this subject in a common-sense manner.

This report provides for standardization by weight. I believe the experts who appeared here this afternoon have definitely shown that if you do that you are going to get into thousands of sizes of containers.

In New Jersey we tried to approach a problem of coordinating weight and volume and found our snags there. We found that there were 50 different grades of apples, all weighing differently, and that to arbitrarily set one weight for a bushel of apples was out of the question. And we found the same commodities grown in different States will vary in weight. Therefore, in the packaging of viscous and semisolid foods especially, you will have different densities, and other factors enter into it, so that in different States different sized 
cans must be provided to contain a pound of the same commodity. Also you have different recipes in the industry, which result in different viscosities and densities, and which again cause differences in the size of containers to contain the same weight.

I was very gratified to hear this afternoon a member of one industry say he refused to make a false container. We have found whisky bottles made up as pints, although they contained only 14 ounces. When I made a statement to that effect on this floor, I was challenged, and it was said that no member of the industry would make up and falsely label a bottle like that. I wonder if the label manufacturers have given us the cooperation they should and could have done. You fellows have run across markings you need a magnifying glass to read. Those things are things that can be corrected. The ethics of the manufacturers should be raised so that they will not put some of those things on the market. But when you get to canned products, you face a big problem, and as I grow older, I am a little more hesitant to jump into these things.

Gentlemen, I think a very splendid efiort has been made here to develop this subject, to show what is wrong, and what we might be able to do. Perhaps we will have to break down this situation into certain commodities that will lend themselves to sale by weight, as against others which should be standardized by volume.

I think the Committee should be continued, because it has done such splendid work, Mr. Pisciotta particularly. I don't believe anybody in the country has ever before made such an extensive study as this. But 1 think there should be even more study and that the Committee should find out if they can really go through with the recommendations in this report which, as I see it, is very arbitrary in recommending something which may not, in effect, work out. It seems almost impossible for the various container manufacturers to meet this, without putting on the market such a multitudinous number of sizes that the same confusion would exist that we encounter at present.

I am wondering whether all of this hasn't been considered in a very able fashion by the Food and Drug Administration in the Department of Agriculture. Surely they must have encountered these things in their experiences through the years. I don't know whether they have been hesitant about approaching standardization or whether they have just chosen the easier way, in advocating that there be a statement of contents on the food package and that everybody shall be guided by that. It is a question, of course, whether we can protect the customer against himself. The average American today has education enough to be able to read and understand a label on the package, if that label is the proper kind of a label. Perhaps, after all, if industry knows what we want, it may clean its own house so that we can get somewhere without an upheaval, which is a thing to avoid.

Have we gone far enough to put these recommendations in a bill before Congress? May not various experts come in and show the impracticability of the plan and demonstrate that it is something which cannot be accomplished? Mr. Pisciotta and his Committee describe what they believe is a simple solution. But I think it has been developed here this afternoon that the problem is not an easy one to solve, that we still have some distance to go yet before you can confidently prescribe the remedy. I think the Committee should by 
all means be continued, in order to contact other industries. No doubt the Committee has done much along this line, but possibly some new thoughts may have been developed today. For these reasons, I shall oppose the motion as it stands, to adopt and approve the present report.

(As an amendment to the motion to adopt the report, a motion was made and seconded that the report be laid on the table but that the Committee be continued and report back to the Conference at some future date.)

Mrr. Levitr. Mr. Chairman, the Food and Drug Act has been mentioned in the debate. You and I know that this act relates primarily to quality. Why should weights and measures departments sit back and rely on that act to regulate quantities. If we can handle the quantitative end, let us do so.

I think the original motion covers the situation; the Committee is to confer with these gentlemen and reach some agreement. If we table this motion, we will just be putting it off another year and we won't be accomplishing anything.

Mr. J. G. Rogens. The recommendations in that report are what will be tabled. If the matter be referred back to a committee with instructions to work it out with the various members of the industries affected, that will put the Conference on record as not taking an arbitrary action. The original motion provides for definite approval of everything in the Committee recommendations, although it has been shown here this afternoon that they cannot be carried out.

(A motion was made and seconded to table the amendment.)

The Acting Chairman. We are voting on the motion to table the amendment.

(The question was taken and the motion was agreed to.)

Mr. ACKerman. Mr. Chairman, speaking on the original motion, I am in favor of the Committee report. A few moments ago a representative of a can company stated that this company would not manufacture a depressed lid to make a gallon can short 8 cubic inches. I want to tell you I have three cans with the label of that company on them. They were measured yesterday by the National Bureau of Standards; one of them is 8.6 , another is 4.7 , and the third 6.2 cubic inches short.

Again, I may say that, through the belp of Mr. O'Keefe, we learned last summer, that there was a carload of salad dressing coming to Minneapolis, short weight. When we investigated, we found glass. containers which had "one quart" blown in the glass, although the bottles would hold this amount only when filled to the overflow point.

If you will permit me, I will read from an article published in a Minneapolis newspaper:

There no longer is misrepresentation, but the elements of "sham" and optical illusion are still present, and not even the glass manufacturer pretends they are not. In fact, he makes a definite point of it. Here are some sample descriptions in the catalog of one manufacturer:

"* * *," pride of all glasses. Thin-blown, heavy sham-bottom crystal glasses. Appears two ounces larger than other heights. The ideal glass for beer service.

The "** * *," a concave heavy sham-bottom, thin-blown glass. Has very fine quality appearance. Looks extra big because of its heavy bottom.

New tall whiskey glass. A fine quality thin-blown clear crystal glass with triple sham-bottorn. Looks exceptionally large, but holds only regular whisky serving. 
Popular whisky glass, heavy pressed. Wide, high-cut flutes shammed, looks large.

The "* * *" beer mug is made of best-quality glass, full finished with extraheavy bottom. Large strong handle. Looks large for its capacity.

Deluxe beer stein, made of best quality glass, finely finished with smooth top and bottom. Has a large, strong handle. Shammed to make it appear large for its capacity.

And so on and on-for the brimming glass or mug that slides across the bar.

The eyes see a lot more than the mouth receives. And if the psychologists took to drinking, what a lot of deductions they could make on optico-mental illusions-deductions with what a powerful kick.

Inasmuch as some glass manufacturers do not hestitate to come out and print phony descriptions in the catalogs and to educate the dealers how to sham and pretend, I think it is high time we adopt the Committee's report.

Mr. Tourteliot. Mr. Chairman, I would regard it as a cooperative act if my friend who has just spoken would let me have a sample of the can of which mention was just made, so that we can run down and stop anything of that nature. I have just completed an investigation that I thought was thorough, of the manufacture of oyster cans all over the country, and I am not aware of any such condition as he cites. But if it exists, I promise you it will be rectified.

Mr. KANZER. I want to put myself on record as approving and commending the report. On the basis of what we heard Mr. Campbell say there need be no hesitation with reference to the capacity basis for liquids; this opened the door completely for 100-percent approval for standard containers for liquids. My friend Joe Rogers thinks that there are considerations which might make us hesitate with reference to the weight basis. However, this motion distinctly provides that the Committee will further confer with the industry. The principle is correct and the report is correct, and I think it should be adopted.

(The question was taken and the motion was agreed to.)

(At this point, at 5:10 p. m., the Conference adjourned to meet at 9:30 a. m., Friday, June 9, 1939.) 
$=1+3+2$

$=(x+2)=$

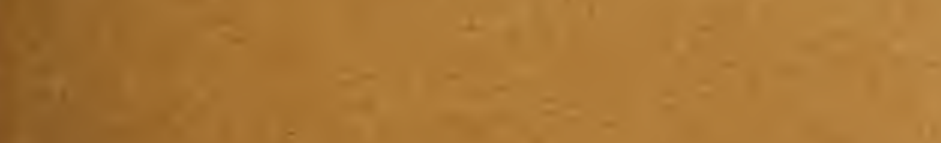

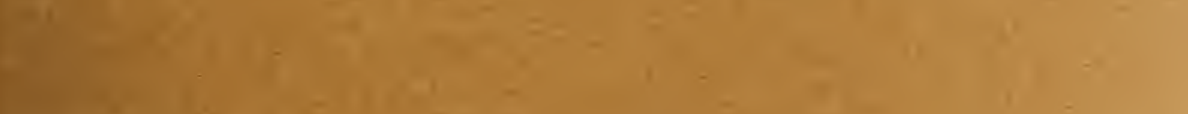

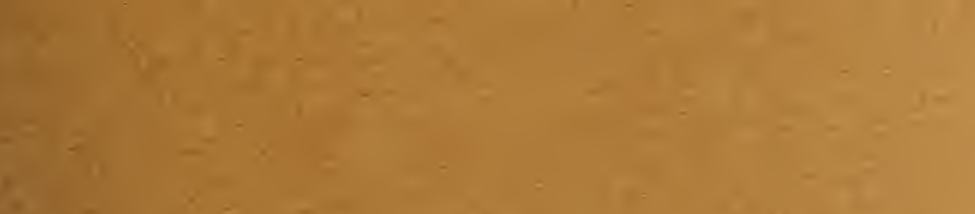

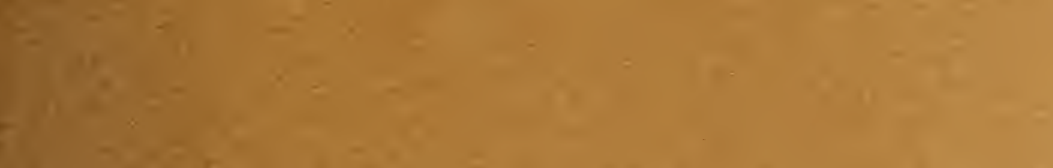

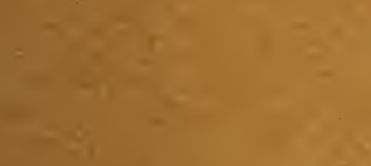

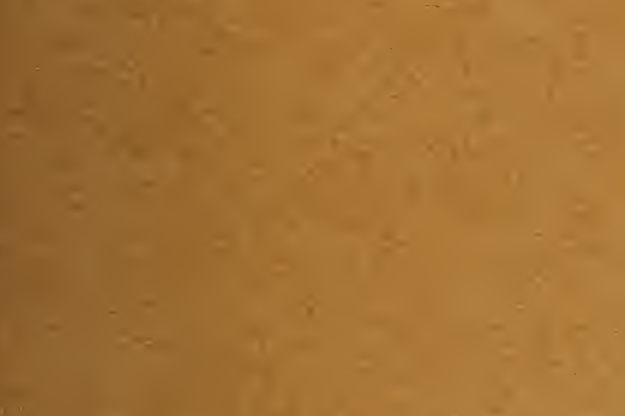

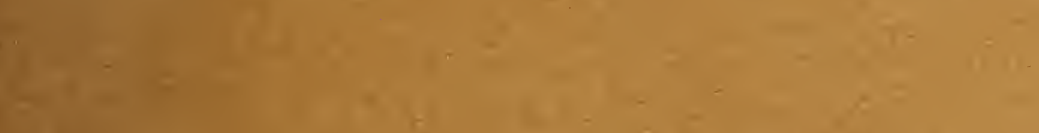

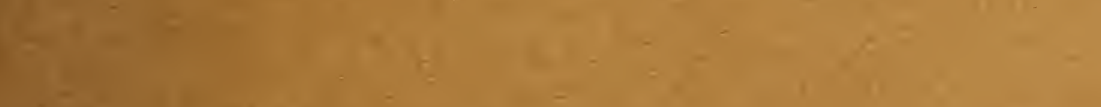

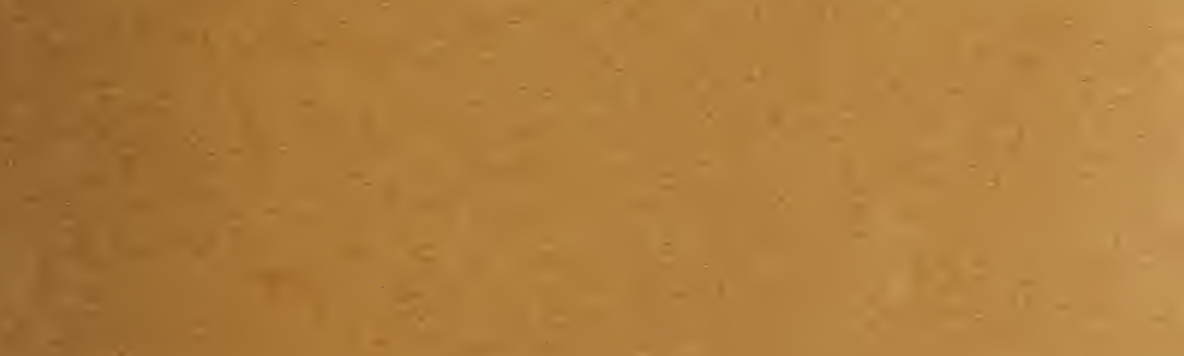

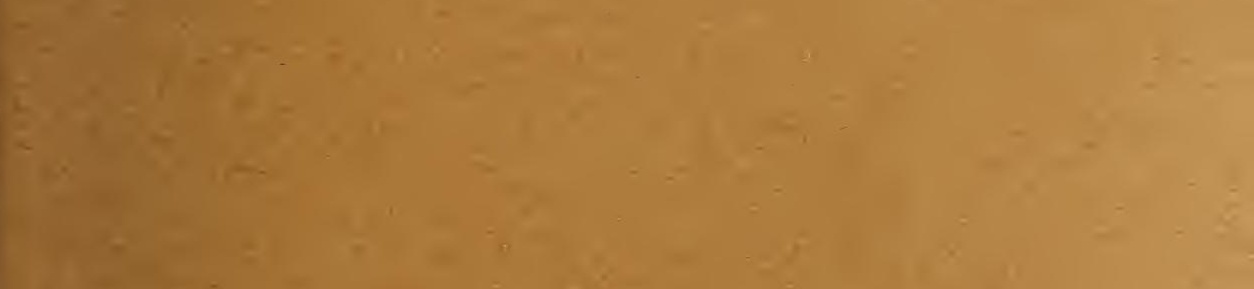

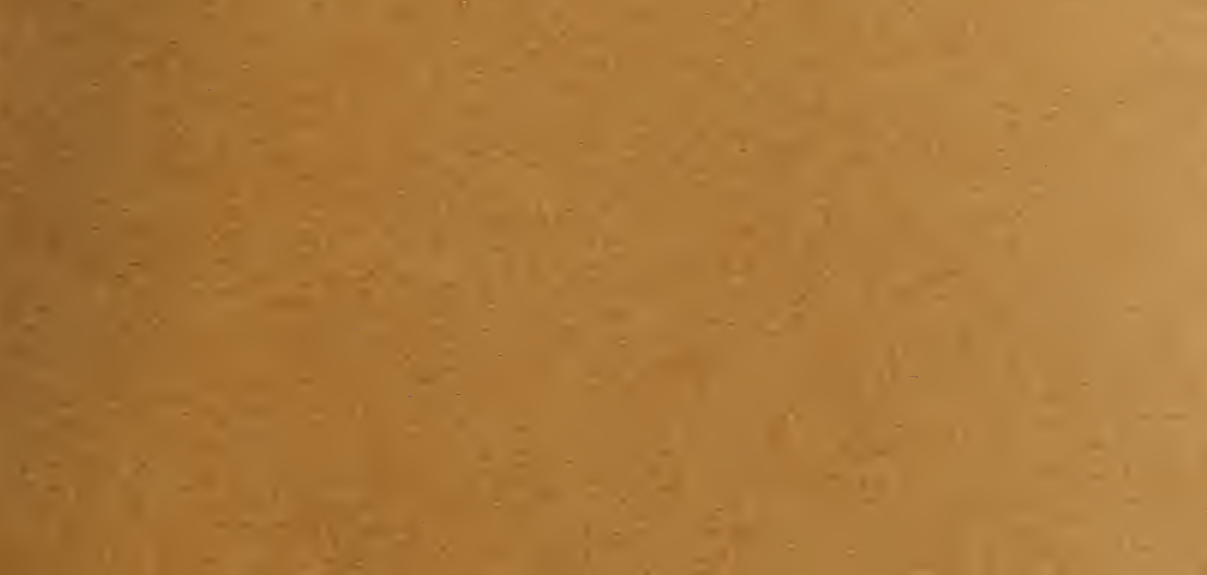




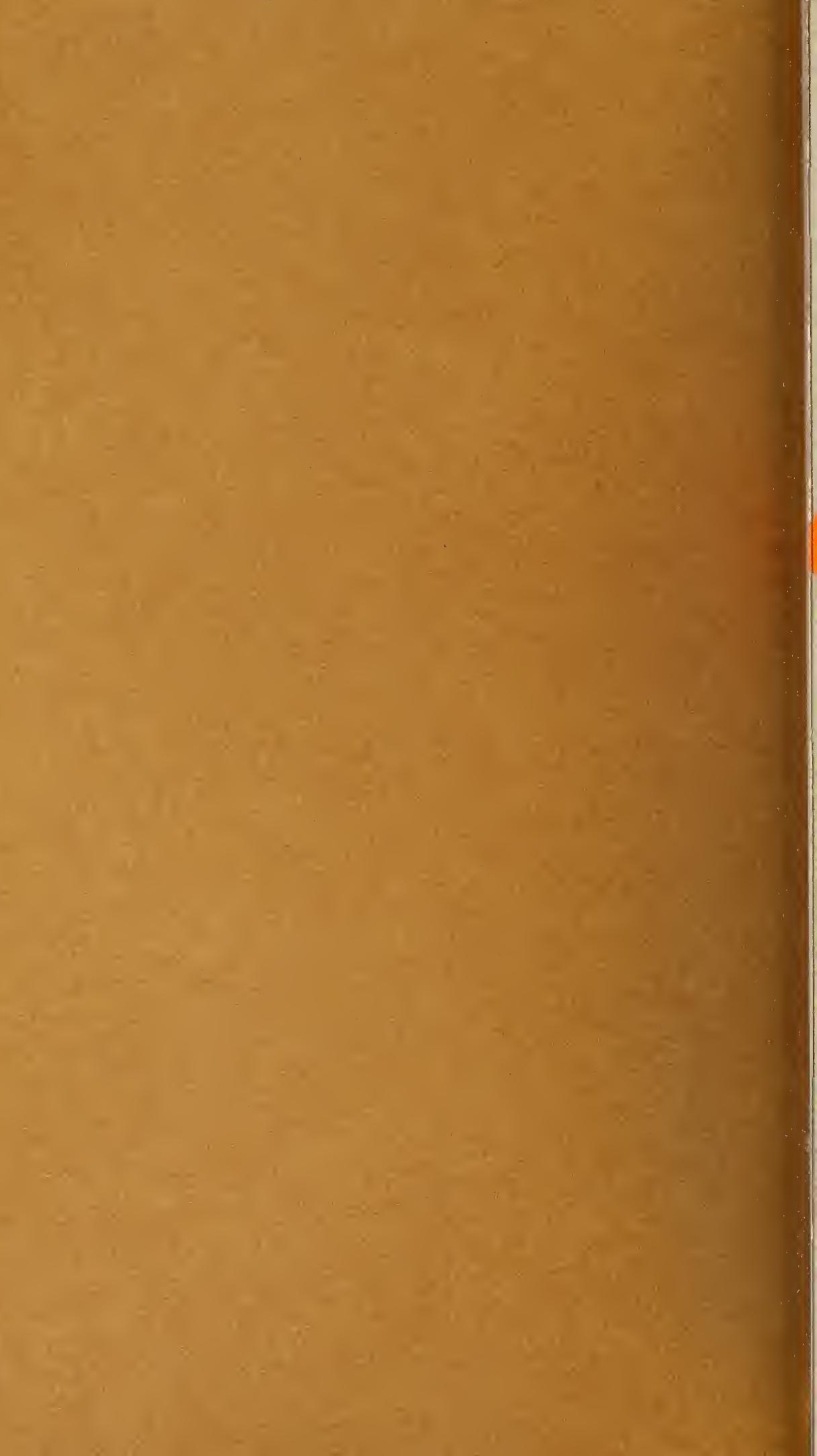

